\title{
Differences in gene expression and cytokine production by crystalline vs. amorphous silica in human lung epithelial cells
}

Timothy N Perkins', Arti Shukla', Paul M Peeters², Jeremy L Steinbacher ${ }^{3}$, Christopher C Landry ${ }^{3}$, Sherrill A Lathrop' ${ }^{1}$, Chad Steele ${ }^{4}$, Niki L Reynaert ${ }^{2}$, Emiel FM Wouters ${ }^{2}$ and Brooke T Mossman ${ }^{1 *}$

\begin{abstract}
Background: Exposure to respirable crystalline silica particles, as opposed to amorphous silica, is associated with lung inflammation, pulmonary fibrosis (silicosis), and potentially with lung cancer. We used Affymetrix/GeneSifter microarray analysis to determine whether gene expression profiles differed in a human bronchial epithelial cell line (BEAS 2B) exposed to cristobalite vs. amorphous silica particles at non-toxic and equal surface areas (75 and $150 \times$ $10^{6} \mathrm{\mu m}^{2} / \mathrm{cm}^{2}$ ). Bio-Plex analysis was also used to determine profiles of secreted cytokines and chemokines in response to both particles. Finally, primary human bronchial epithelial cells (NHBE) were used to comparatively assess silica particle-induced alterations in gene expression.
\end{abstract}

Results: Microarray analysis at 24 hours in BEAS 2B revealed 333 and 631 significant alterations in gene expression induced by cristobalite at low (75) and high $\left(150 \times 10^{6} \mathrm{\mu m}^{2} / \mathrm{cm}^{2}\right)$ amounts, respectively $(p<0.05 / \mathrm{cut}$ off $\geq 2.0$-fold change). Exposure to amorphous silica micro-particles at high amounts $\left(150 \times 10^{6} \mu \mathrm{m}^{2} / \mathrm{cm}^{2}\right)$ induced 108 significant gene changes. Bio-Plex analysis of 27 human cytokines and chemokines revealed 9 secreted mediators $(p<0.05)$ induced by crystalline silica, but none were induced by amorphous silica. QRT-PCR revealed that cristobalite selectively up-regulated stress-related genes and cytokines (FOS, ATF3, IL6 and IL8) early and over time $\left(2,4,8\right.$, and 24 h). Patterns of gene expression in NHBE cells were similar overall to BEAS 2 B cells. At $75 \times 10^{6} \mu m^{2} /$ $\mathrm{cm}^{2}$, there were 339 significant alterations in gene expression induced by cristobalite and 42 by amorphous silica. Comparison of genes in response to cristobalite $\left(75 \times 10^{6} \mathrm{\mu m}^{2} / \mathrm{cm}^{2}\right)$ revealed $60 \mathrm{common}$, significant gene alterations in NHBE and BEAS 2B cells.

Conclusions: Cristobalite silica, as compared to synthetic amorphous silica particles at equal surface area concentrations, had comparable effects on the viability of human bronchial epithelial cells. However, effects on gene expression, as well as secretion of cytokines and chemokines, drastically differed, as the crystalline silica induced more intense responses. Our studies indicate that toxicological testing of particulates by surveying viability and/or metabolic activity is insufficient to predict their pathogenicity. Moreover, they show that acute responses of the lung epithelium, including up-regulation of genes linked to inflammation, oxidative stress, and proliferation, as well as secretion of inflammatory and proliferative mediators, can be indicative of pathologic potential using either immortalized lines (BEAS 2B) or primary cells (NHBE). Assessment of the degree and magnitude of these responses in vitro are suggested as predictive in determining the pathogenicity of potentially harmful particulates.

\footnotetext{
* Correspondence: brooke.mossman@uvm.edu

'Department of Pathology, University of Vermont College of Medicine, 89

Beaumont Avenue, Burlington, VT 05405, USA

Full list of author information is available at the end of the article
} 


\section{Background}

Occupational and environmental exposure to fine and ultrafine particulates is rapidly becoming an overwhelming area of concern. With increasing numbers and compositional heterogeneity of potentially harmful natural and synthetic particulates, there is a vital need for screening assays to determine their potential pathogenicity. Crystalline silica particles are known to cause silicosis (a pneumoconiosis) and have other detrimental respiratory effects when inhaled in excessive amounts [1]. Airborne exposures are also associated with lung inflammatory diseases, increased susceptibility to infection, as well as lung cancers, especially in smokers [2,3]. Crystalline silica was stated to be a Class I carcinogen (IARC 1997) which was recently restated (IARC 2010) [4], though epidemiologic data are inconsistent, and its carcinogenic potential in non-smokers remains controversial [5]. Exposure to crystalline silica is associated with industries and occupations including, sandblasting, ceramics, cement manufacture, construction, and quarry and foundry workers [2,6-9]. Although crystalline silica exists in many different polymorphs, those of particular concern are the naturally occurring polymorphs quartz, cristobalite and tridymite [10]. Cristobalite was used in studies here because of its bioreactivity in a rat inhalation model [11].

Inhalation of crystalline silica or other pathogenic minerals such as asbestos and airborne particulate matter $(\mathrm{PM})$ results in lung injury by mechanisms, which are not well understood $[12,13]$. Crystalline silica particles induce extensive inflammatory and proliferative effects in vitro and in vivo [14-20]. Activation of several signaling pathways, including the mitogen-activated protein kinases (MAPKs) [21-23] as well as transcription factor complexes including activator protein-1 (AP-1) [24] and nuclear factor kappa B (NF $\kappa \mathrm{B})$, are thought to contribute to the pro-inflammatory, toxic and mitogenic effects of silica [25]. Understanding the broad spectrum of initial events induced by particulate-cell interactions is crucial to revealing the molecular mechanisms that contribute to inflammation, abnormal proliferation and cross-talk between epithelial cells and other cell types in the lung.

Here we focused on lung epithelial cells, which initially interact with respirable particles after inhalation to provide insight into molecular events initiating silicainduced disease processes. Since surface area, as opposed to equal mass concentration, has been shown to be a more appropriate parameter of dosing to determine the effects of fine and ultrafine particulates in biological systems [26-29], human bronchial epithelial cells were exposed to crystalline silica (cristobalite) or amorphous silica (synthetic, dense silica spheres) at non-toxic and equal surface area concentrations. As previous studies from our group have shown that the magnitude and duration of gene expression alterations in human mesothelial cells by asbestos fibers may be predictive of their pathogenic potential [30-32], we utilized robust microarray profiling to compare responses of human lung epithelial cells to pathogenic crystalline vs. amorphous silica. Our findings link the extent of changes in gene expression and cytokine production to silica crystallinity and pathogenicity in silicosis.

\section{Results and Discussion \\ Cristobalite and amorphous silica particles have equal effects on viability of BEAS $2 B$ cells}

Surface area is a better metric than mass, thus doses have been measured on a surface area basis as the biological activity of particles is largely based on their respective surface characteristics [29,33-35]. Much of this is accredited to the ability of pathogenic particles to produce reactive oxygen and nitrogen species (ROS and RNS) [36] that promote inflammatory responses and cellular injury [37]. The surface areas of cristobalite and amorphous silica particles (dense silica micro-spheres) were determined by BET nitrogen adsorption analysis [32]. Table 1 presents the surface area/unit mass $\left(\mathrm{m}^{2} / \mathrm{g}\right)$ and other properties of cristobalite and amorphous silica particles, including chemical composition $\left(\mathrm{SiO}_{2}\right)$, which is confirmed in (Additional file 1) by SEM-EDS analysis. In addition, the size distribution of cristobalite and amorphous silica particles was determined (Additional file 2). It should be noted that in these studies, a specific type of amorphous silica was used (micron-sized, dense, spheres synthesized by hydrolysis reactions) and therefore conclusions may not necessarily be extrapolated to other amorphous silica types. To avoid use of lethal concentrations of particles, we first performed cell viability assays over a range of concentrations. Both particles

Table 1 Silica particle characterization

\begin{tabular}{|c|c|c|c|c|c|c|}
\hline Silica Particle & Chem. Comp. & $\%$ Purity & S.A. $\left(\mathrm{m}^{2} / \mathrm{g}\right)^{\mathrm{a}}$ & Mean size $(\mu \mathrm{m})^{\mathrm{b}}$ & Particles/mg & Source \\
\hline Cristobalite & $\mathrm{SiO}_{2}$ & *95.5 \pm 0.03 & 5.1 & $2.16 \pm 2.00$ & - & C\&E Mineral Corp, King of Prussia, PA \\
\hline Amorphous & $\mathrm{SiO}_{2}$ & $>99$ & 2.2 & $3.55 \pm 0.45$ & $20.33 \times 10^{6}$ & University of Vermont, Dept. of Chemistry \\
\hline
\end{tabular}


had dose-responsive effects on viability, inducing only about $15 \%$ loss of viability (non-significant) at highest concentrations $\left(150 \times 10^{6} \mu \mathrm{m}^{2} / \mathrm{cm}^{2}\right)$ over a $24 \mathrm{~h}$ period (Figure 1). Both a low $\left(75 \times 10^{6} \mu \mathrm{m}^{2} / \mathrm{cm}^{2}\right)$ and high dose $\left(150 \times 10^{6} \mu \mathrm{m}^{2} / \mathrm{cm}^{2}\right)$ of crystalline silica particles and a high dose $\left(150 \times 10^{6} \mu \mathrm{m}^{2} / \mathrm{cm}^{2}\right)$ of amorphous silica were evaluated by microarray and Bio-Plex analysis for gene expression and cytokine/chemokine secretion, respectively.

\section{Cristobalite and amorphous silica particles interact with and are taken up by BEAS $2 \mathrm{~B}$ cells}

To determine whether human lung epithelial cells took up both particle types, scanning electron micrographs of BEAS $2 \mathrm{~B}$ cells exposed to silica particles $\left(75 \times 10^{6} \mu \mathrm{m}^{2} /\right.$ $\mathrm{cm}^{2}$ ) were examined at 2 and $24 \mathrm{~h}$ (Figure 2). The presence of silica particles was confirmed by electron dispersion spectroscopy (EDS) analysis, in which a spectrum was taken of a point "on-particle" showing a strong silicon $(\mathrm{Si})$ peak and an "off-particle" spectrum, which contained no $(\mathrm{Si})$ peak. Both cristobalite and amorphous silica particles interacted with cells at $2 \mathrm{~h}$ and were internalized by $24 \mathrm{~h}$ (Figure 2). No major toxic effects were observed, correlating with results of cell viability studies. Based on these results, we investigated alterations in gene expression and mediator secretion at these non-toxic particle doses.
Microarray analysis reveals robust changes in gene expression profiles in BEAS 2B cells exposed to cristobalite vs. amorphous silica particles

It has been shown both in vitro and in vivo that crystalline silica particles are more biologically active and pathogenic than amorphous silica particles [20,38-40]. Therefore, we sought to determine if there were significant differences in how different silica particles (crystalline vs. amorphous) would affect gene expression and cytokine/chemokine secretion at equal surface area concentrations in the BEAS 2B immortalized cell line. Affymetrix/GeneSifter analysis of BEAS $2 \mathrm{~B}$ cells exposed to cristobalite silica at 75 and $150 \times 10^{6} \mu \mathrm{m}^{2} / \mathrm{cm}^{2}$ were compared to patterns using amorphous silica particles at $150 \times 10^{6} \mu \mathrm{m}^{2} / \mathrm{cm}^{2}$ for $24 \mathrm{~h}$, the time point of maximum gene expression observed with pathogenic particulates in previous studies using human mesothelial cells exposed to asbestos [30-32], primary human airway epithelial cells exposed to PM fractions [41] or chrysotile asbestos [42]. A dose-responsive pattern was observed with cristobalite silica that induced a total of 333 and 631 significant gene changes at 75 and $150 \times 10^{6} \mu \mathrm{m}^{2} / \mathrm{cm}^{2}$, respectively ( $\mathrm{p}<0.05$ with a cut-off of $\geq 2$.0-fold change compared to controls). In addition, expression of certain genes was dose-responsive as well. For instance, matrix metallopeptidase 1 (MMP1) gene expression was increased 16-fold and 44-fold at 75 and $150 \times 10^{6} \mu \mathrm{m}^{2} /$

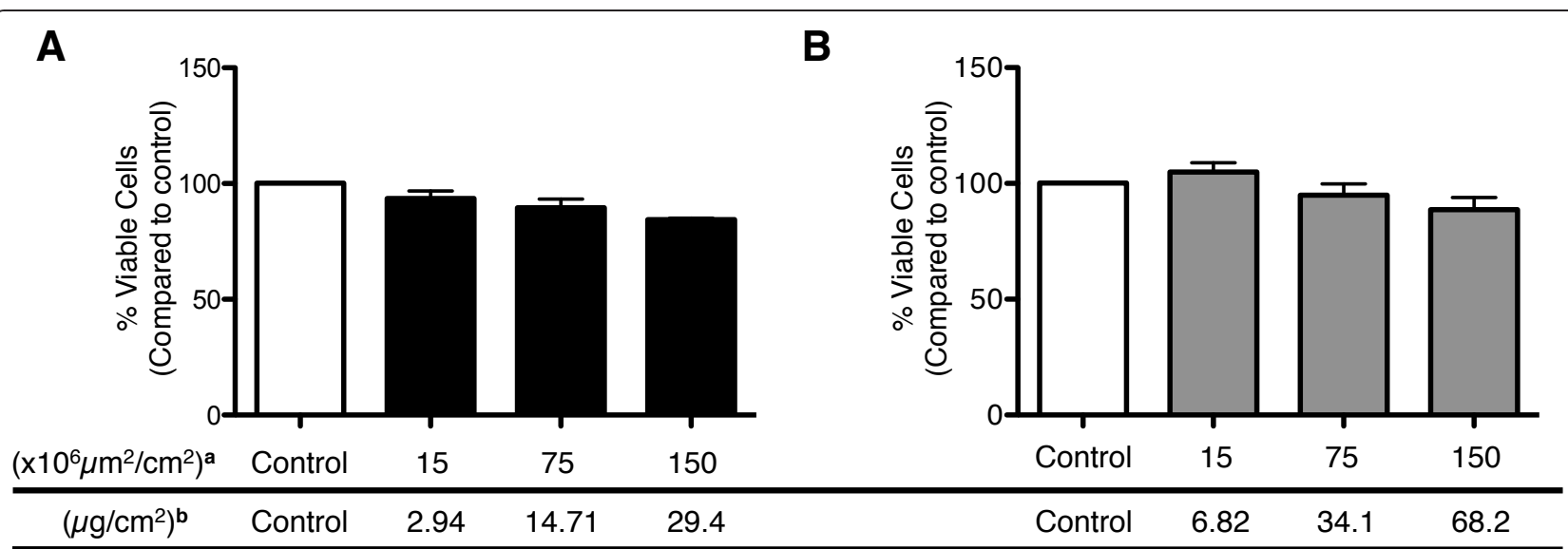

a Surface area concentration

b Mass concentration

$\square$ Control

Cristobalite silica

$\square$ Amorphous silica

Figure 1 Assessment of BEAS 2B cell viability after exposure to silica particles. Cell viability assessed by the Trypan blue exclusion assay of cells exposed to cristobalite (A) and amorphous silica particles (B) for $24 \mathrm{~h}$. Results are expressed as the mean percent viable cells \pm SEM compared to unexposed controls and are representative of 3 independent experiments ( $\mathrm{N}=3$ for each group in each experiment). ${ }^{\mathbf{a}}$ denotes the surface area concentrations expressed as $\left(\times 10^{6} \mu \mathrm{m}^{2} / \mathrm{cm}^{2}\right)$ and ${ }^{\mathbf{b}}$ denotes the respective mass concentrations of particles used ( $\left.\mu \mathrm{g} / \mathrm{cm}^{2}\right)$. Concentrations presented are represented by surface area for all other figures and tables. 

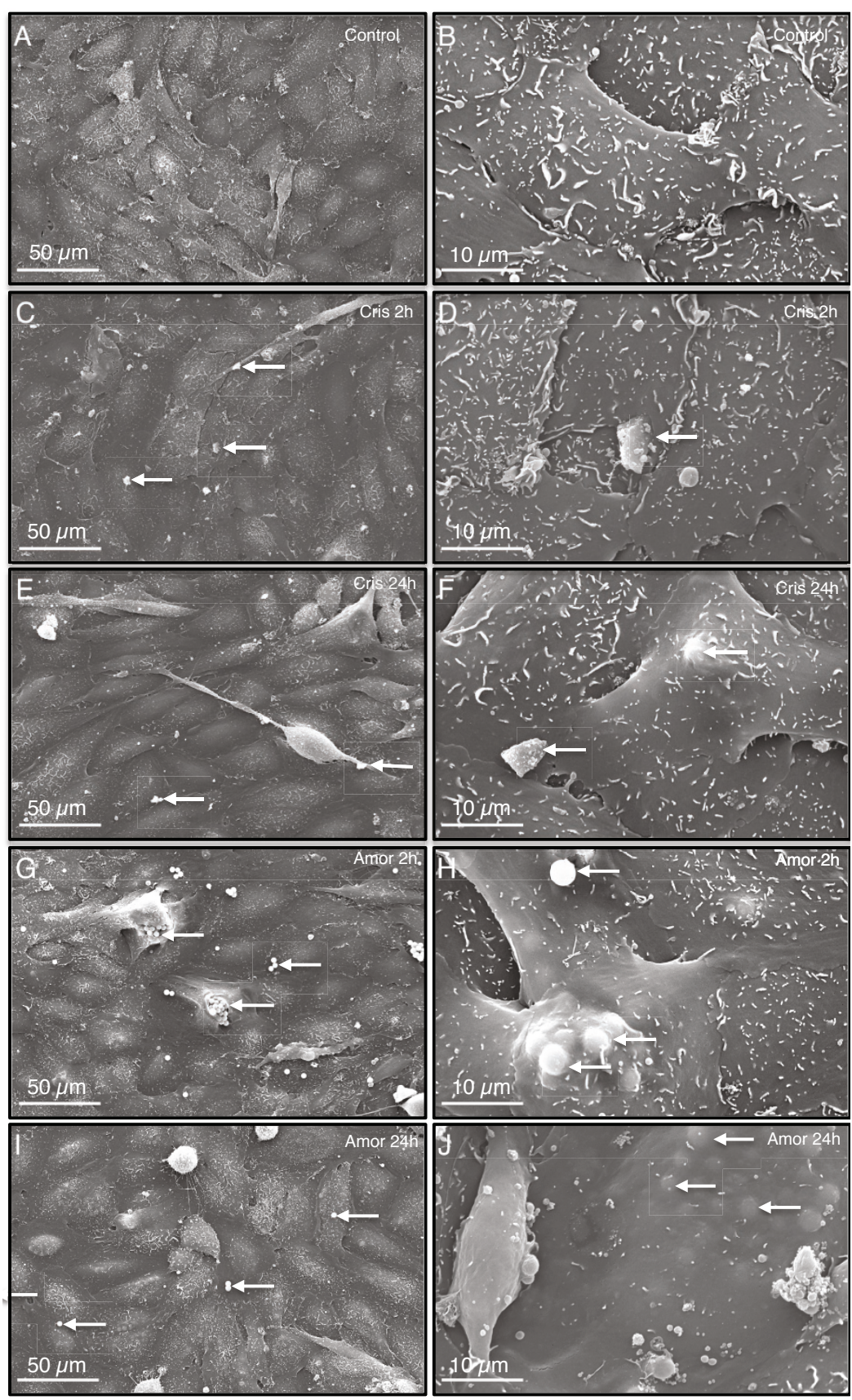

Figure 2 Interaction and uptake of silica particles by BEAS 2B cells. Scanning Electron Micrographs of BEAS 2B cells. Unexposed controls (A, B), exposed to cristobalite $\left(75 \times 10^{6} \mathrm{\mu m}^{2} / \mathrm{cm}^{2}\right)$ for $2 \mathrm{~h}(\mathbf{C}, \mathbf{D}), 24 \mathrm{~h}(\mathbf{E}, \mathbf{F})$ and amorphous silica $\left(75 \times 10^{6} \mu \mathrm{m}^{2} / \mathrm{cm}^{2}\right)$ for $2 \mathrm{~h}(\mathbf{G}, \mathbf{H})$ and $24 \mathrm{~h}(\mathbf{I}, \mathbf{J})$. Panels on the left are at low magnification (500x) scale bar $=50 \mu \mathrm{m}$ and on the right at high magnification (2500x) scale bar $=10 \mu \mathrm{m}$. White arrows indicate silica particles.

$\mathrm{cm}^{2}$, respectively (Table 2 ). This dose responsive trend was observed overall in mRNA levels of the 10 most highly expressed genes after cristobalite exposures as presented in Table 2. However, amorphous silica particles, at the highest surface area concentration $(150 \times$ $10^{6} \mathrm{\mu m}^{2} / \mathrm{cm}^{2}$ ), induced only 108 significant gene changes, nearly 6 -fold less than cristobalite silica (Figure 3A). Of the 108 changes induced by amorphous silica, 93 of these changes were also induced by cristobalite silica at the same concentration.

Gene ontology (GO) analysis then was used to categorize changes in gene expression caused by silica 
Table 2 Top 10 genes affected by $24 \mathrm{~h}$ exposure to silica particles in BEAS 2B

\begin{tabular}{|c|c|c|c|}
\hline \multirow[t]{3}{*}{ Gene Name (Abbreviation) } & \multicolumn{3}{|c|}{ Fold Change $^{a}$} \\
\hline & \multicolumn{2}{|c|}{ Cristobalite } & \multirow{2}{*}{$\begin{array}{c}\text { Amorphous } \\
150^{\mathrm{b}}\end{array}$} \\
\hline & $75^{\mathrm{b}}$ & $150^{\mathrm{b}}$ & \\
\hline \multicolumn{4}{|l|}{ Up-regulated $\Delta$} \\
\hline Myxovirus (influenza virus) resistance 2 (mouse) (MX2) & 20.86 & 73.76 & 22.33 \\
\hline Matrix metallopeptidase 1 (interstitial collagenase) (MMP1) & 16.12 & 44.68 & 18.75 \\
\hline Sodium Channel, voltage-gated, type III, beta (SCN3B) & 15.33 & 20.54 & NC \\
\hline 2'-5'-oligoadenylate-synthetase 2, 69/71 kDa (OAS2) & 13.56 & 34.77 & 12.17 \\
\hline Myxovirus (influenza virus) resistance 1, interferon-inducible protein p78 (mouse) (MX1) & 9.61 & 23.33 & 8.72 \\
\hline Interferon-induced protein 44-like (IFI44L) & 7.64 & 22.82 & 8.63 \\
\hline Interferon-induced protein 44 (IFI44) & 7.51 & 19.90 & 8.24 \\
\hline B-cell Linker (BLNK) & 7.24 & 9.32 & NC \\
\hline BTG family, member 2 (BTG2) & 7.22 & 8.56 & NC \\
\hline Carcinoembryonic antigen-related cell adhesion molecule 1 (CEACAM1) & 7.19 & 11.05 & NC \\
\hline 2'-5'-oligoadenylate synthetase 1, 40/46kDa (OAS1) & 7.09 & 20.53 & 6.75 \\
\hline Interferon, alpha-inducible protein 27 (IFI27) & 6.59 & 17.62 & 6.15 \\
\hline 2'-5'-oligoadenylate synthetase-like (OASL) & 6.80 & 18.85 & 6.92 \\
\hline Radical S-adenosyl methionine domain containing (RSAD1) & 5.45 & 23.25 & 6.09 \\
\hline Interleukin 24 (IL24) & 3.88 & 8.54 & 6.47 \\
\hline \multicolumn{4}{|l|}{ Down-regulated $\mathbf{v}$} \\
\hline Collagen, type I, alpha 2 (COL1A2) & 6.08 & 10.86 & 2.12 \\
\hline Hypoxia inducible factor 3, alpha subunit (HIF3A) & 4.51 & 7.18 & 3.94 \\
\hline Collagen, type I, alpha 1 (COL1A1) & 4.17 & 5.52 & NC \\
\hline Methyltransferase like 7A (METTL7A) & 4.11 & 5.67 & 2.89 \\
\hline Cytochrome P450, family 4, subfamily B, polypeptide 1 (CYP4B1) & 3.93 & 5.55 & 3.07 \\
\hline Olfactomedin-like 3 (OLFML3) & 3.91 & 5.28 & 2.06 \\
\hline Mitogen-activated protein kinase kinase 6 (MAP2K6) & 3.86 & 4.78 & 3.21 \\
\hline Collagen, type XI, alpha 1 (COL11A1) & 3.85 & 5.46 & NC \\
\hline Potassium inwardly-rectifying channel, subfamily J, member 16 (KCNJ16) & 3.78 & 7.11 & 3.49 \\
\hline Cannabinoid receptor 1 (brain) (CNR1) & 3.75 & 5.44 & 3.48 \\
\hline Calcium channel, voltage-dependent, alpha 2/delta subunit 3 (CACNA2D3) & 3.53 & 3.49 & 2.65 \\
\hline Solute carrier family 38, member 4 (SLC38A4) & 3.16 & 3.76 & 2.65 \\
\hline Leucine rich repeat containing 17 (LRRC17) & 3.14 & 5.07 & 3.61 \\
\hline Protocadherin 9 (PCDH9) & 2.98 & 3.69 & 2.65 \\
\hline
\end{tabular}

Top 10 genes in BEAS 2 B cells up and down-regulated by 24-hour exposure to cristobalite silica at 75 and $150 \times 10^{6} \mu^{2} / \mathrm{cm}^{2}$ and amorphous silica particles at $150 \times 10^{6} \mathrm{\mu m}^{2} / \mathrm{cm}^{2}$.

${ }^{a}$ Fold change (mRNA) expression $(p<0.05)$ cut-off $\geq 2.0$-fold compared to controls $(n=3)$.

${ }^{b}$ Silica particle concentrations: $\left(\times 10^{6} \mu \mathrm{m}^{2} / \mathrm{cm}^{2}\right)$

NC $=$ No Change

particle exposures (Figure 3B-D). Ten categories of interest (cell signaling, cell adhesion, cell proliferation, apoptosis, regulation of programmed cell death, protein metabolic processes, immune response, cell motility, oxidation-reduction, and cell matrix adhesion) were used to classify gene changes [30-32]. Interestingly, patterns of both cristobalite silica and amorphous silicainduced mRNA expression were similar, with most gene expression alterations related to cell signaling and proliferation, apoptosis, protein metabolic processes and immune responses. Though the intensity of gene changes (both in number and magnitude or fold-change) was dose-dependent, overall the same patterns of change were seen (Additional file 3). These five categories account for 77,73 and $80 \%$ of gene changes in BEAS $2 B$ cells exposed to cristobalite at 75 and $150 \times 10^{6} \mu \mathrm{m}^{2} /$ $\mathrm{cm}^{2}$ and amorphous silica at $150 \times 10^{6} \mu \mathrm{m}^{2} / \mathrm{cm}^{2}$, respectively.

Table 2 lists the top 10 gene changes induced by cristobalite vs. amorphous silica. The majority of the top 10 up-regulated genes are related to immune response (OAS1, OAS2, OASL, IFI44, IFI44L, BLNK), apoptosis (MX1, BTG2, IL24 and IFI27) cell signaling (MX2) and dissolution of extracellular matrix (MMP1). These genes may contribute to the development of silicosis or, in the case of $M M P 1$, repair of lung injury. Similar changes in 


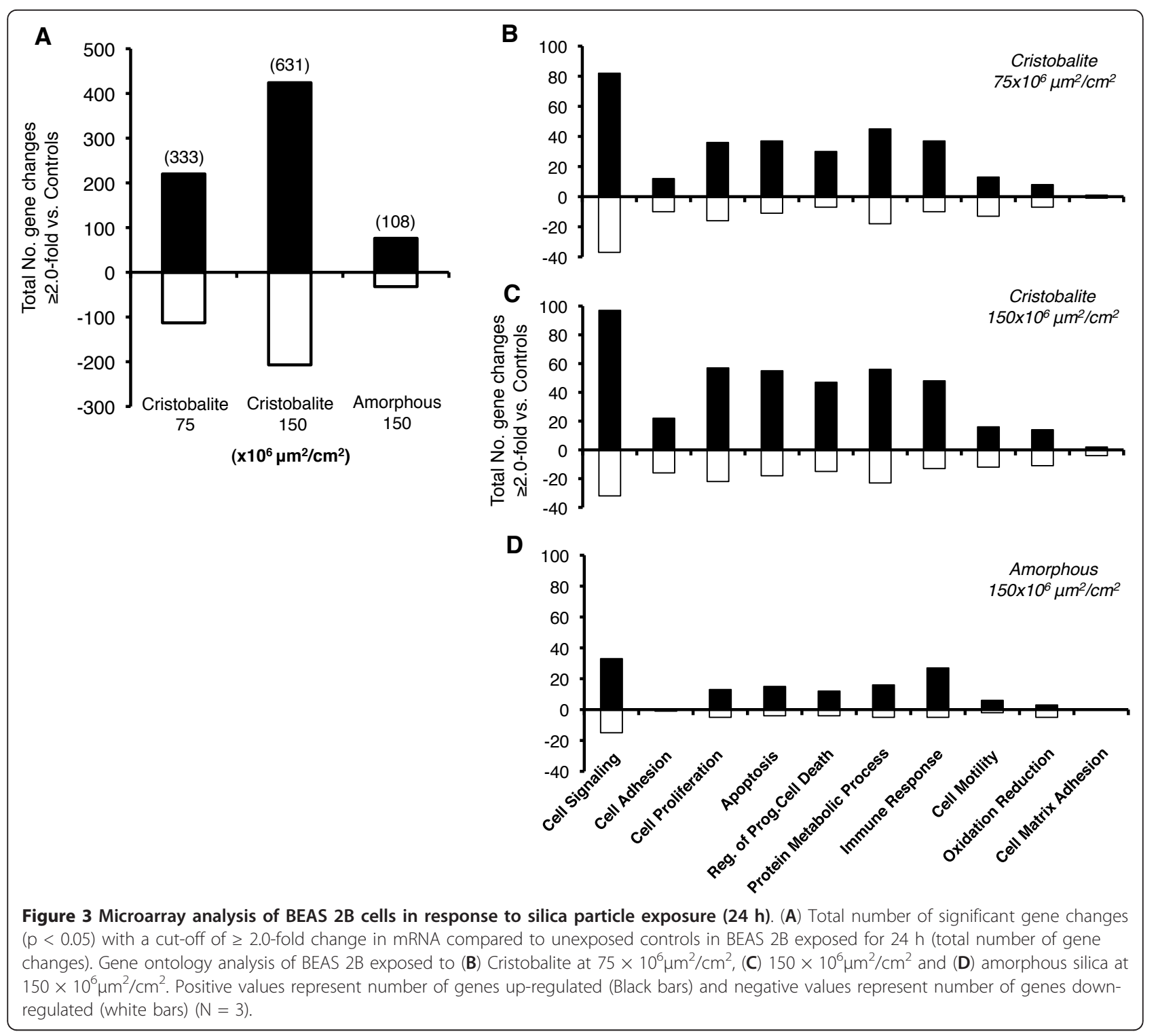

gene expression were observed in a recent study investigating common gene expression responses of macrophages to a number of pathogens including toll-like receptor (TLR) agonists, Salmonella, and silica nanoparticles in which the authors described a "macrophage core response module" [43]. Common changes compared with results in Table 2 include: $M X 1, M X 2$, $O A S 1, O A S 2$, and IFI44. In our studies, several other genes included in this "macrophage core response module" were also altered in expression ( $\mathrm{p}<0.05)$ by cristobalite including EGR1, EGR2, FOS, GADD45B, IFIT1, IFIT2, JUN, MAFB, PLAU, and PTGS1. These results indicate that foreign materials consistently affect a number of common genes in both macrophages and lung epithelial cells. The specific roles these genes play in the development of lung disease is not well understood; however, they appear to be elicited in acute responses to foreign materials and infectious agents. How these rapid responses affect epithelial cells and macrophages, respectively as well as cross-talk between these cells, is not understood, but they may be important, initial mechanisms of cell response to crystalline silica.

Steady state mRNA levels of stress-related and inflammatory genes are induced early and selectively by cristobalite in BEAS 2B cells

Based on the results of our microarray analyses, we investigated some genes of interest using qRT-PCR to confirm changes found in microarrays as well as to determine their time-course of induction in BEAS $2 B$ cells. Genes investigated (up-regulated by cristobalite at 75 and $150 \times 10^{6} \mu \mathrm{m}^{2} / \mathrm{cm}^{2}$ in microarray) included the 
early response gene $F O S$ (2.12, 3.51-fold), a member of the activator protein-1 (AP-1) transcription factor complex [44], activating transcription factor 3 ATF3 (2.68, 3.16 -fold), which is up-regulated in gene-profiling by several particulates in human mesothelial cells and primary bronchial epithelial cells $[30-32,42]$, and the proinflammatory cytokines IL6 (2.12, 2.59-fold) and IL8 (2.12, 2.65-fold), both shown to be up-regulated by crystalline silica in A549 cells and a number of in vitro and in vivo models [21,45-49].

In all cases, mRNA levels of these genes were only upregulated significantly by crystalline in contrast to amorphous silica (Figure 4). Consistent with its role as an early response gene, FOS expression was significantly increased at $2 \mathrm{~h}$ and peaked at $4 \mathrm{~h}$ post-exposure to silica (Figure 4A). These findings indicate that stressresponse genes are rapidly activated by crystalline silica but not by amorphous silica particles in human lung epithelial cells. It has previously been demonstrated that FOS expression is increased by alpha quartz (DQ12 and Min-U-Sil), and coal-mine dust with high quartz concentrations in a murine alveolar type II cell line (C10) $[23,50]$. In addition, $A T F 3$ was significantly up-regulated by crystalline silica as early as 4 and up to $24 \mathrm{~h}$ (Figure 4B). In studies investigating gene expression induced by asbestos in human mesothelial and bronchial epithelial cells $[31,32,42,51]$, as well as by cigarette smoke extract in 3T3 fibroblasts [52] and benzo(a)pyrine diol-epoxide (BPDE) in bronchial epithelial cells [42], ATF3 expression is significantly increased. Moreover, Shukla et al. [32], demonstrated that ATF3 expression was causally linked to the release of cytokines from human mesothelial cells exposed to asbestos fibers using siRNA approaches.

To our knowledge, up-regulation of ATF3 by crystalline silica particles has not been reported previously. It

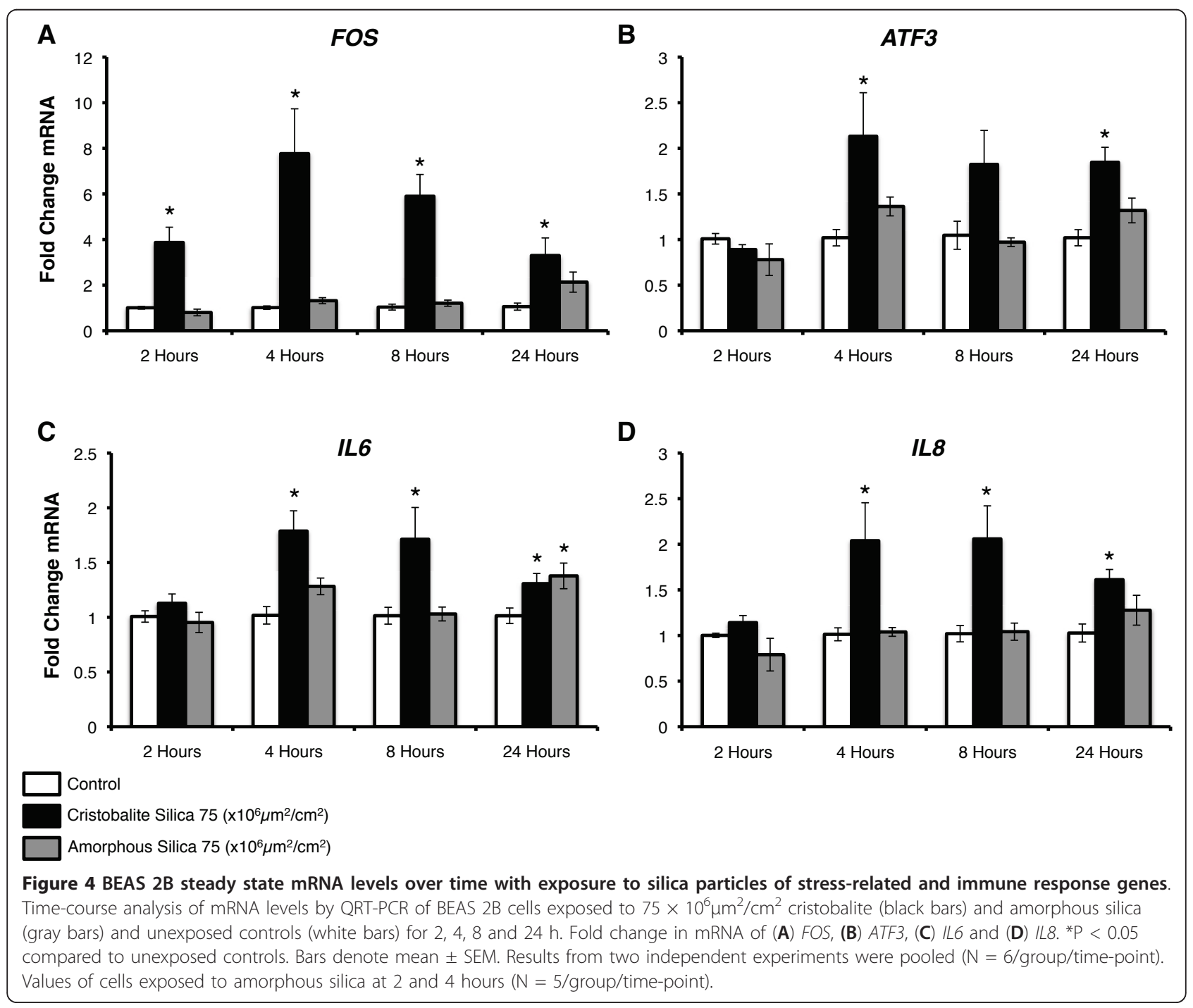


is possible, based on our earlier work [32] and results below, that ATF3 may be linked to secreted-mediator release from bronchial epithelial cells. For example, IL6 and $I L 8$, which are linked to early inflammatory response, are up-regulated at the mRNA level and released from lung epithelial cells, alveolar macrophages, and in BALF of mice exposed to crystalline silica [21,45-48]. Our studies show that IL6 and IL8 mRNA levels are up-regulated significantly $(\mathrm{p}<0.05)$ at 4,8 , and $24 \mathrm{~h}$ by cristobalite (Figure $4 \mathrm{C}, \mathrm{D}$ ). In summary, data in Figure 4 show that stress-response and proinflammatory genes are up-regulated early and over time, peaking at $4 \mathrm{~h}$, in human bronchial epithelial cells by crystalline, but not amorphous silica particles. As both particle types are similar in size and chemical composition, non-toxic to, and taken up by BEAS $2 \mathrm{~B}$ cells, their differential effects on gene expression may be related to differences in crystallinity.

\section{Cristobalite silica selectively induces pro-inflammatory and angiogenic cytokine and chemokine secretion from BEAS $2 B$ cells}

Figure 5 shows the results of Bio-Plex assays. Levels of 9 cytokines/chemokines in medium were increased $(\mathrm{p}<$ 0.05 ) selectively by cristobalite and 2 were decreased by both silica types when compared to unexposed control cells. As for the remainder of the 27 cytokines and chemokines surveyed, 8 (IFN $\gamma$, IP-10, IL-1 $\beta$, IL-7, IL-9, IL10 , MIP- $1 \alpha$ and MIP-1 $\beta$ ) yielded insignificant changes when compared to unexposed controls, and 8 (IL-1ra,

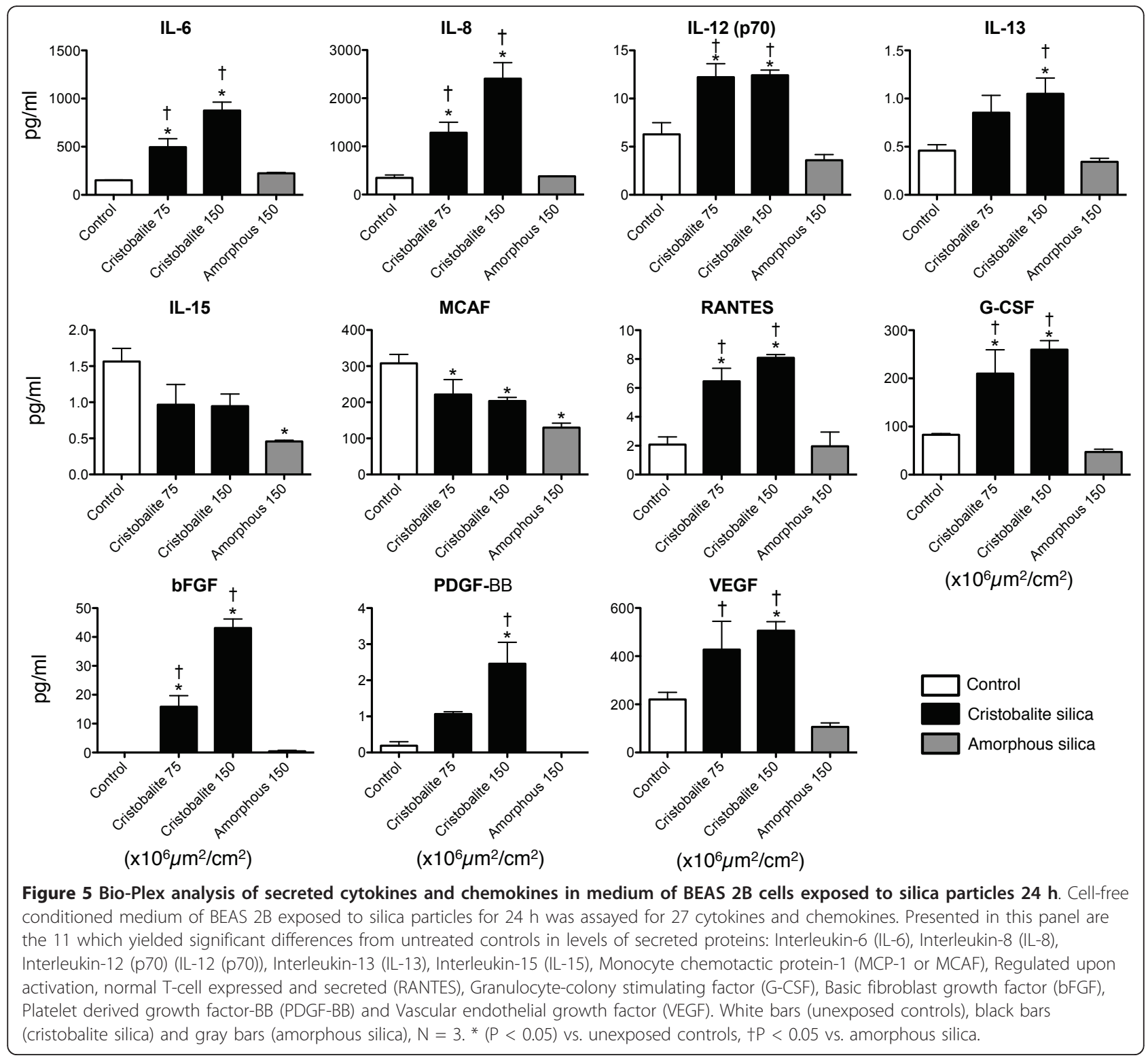


IL-2, IL-4, IL-5, IL-17, Eotaxin, GM-CSF and TNF $\alpha$ ) were below the lowest detection limit of the assay. Exposure of BEAS 2B cells to cristobalite at 75 and 150 $\times 10^{6} \mu \mathrm{m}^{2} / \mathrm{cm}^{2}$ for $24 \mathrm{~h}$ caused dose-responsive and significant release of Interleukin-6 (IL-6), IL-8, IL-12 (p70), IL-13, regulated on activation normal $\mathrm{T}$-cell expressed and secreted (RANTES), granulocyte colony-stimulating factor (G-CSF), basic fibroblast growth factor (bFGF/ FGF-2), platelet-derived growth factor-BB (PDGF-BB), and vascular endothelial growth factor (VEGF) (Figure 5). Interestingly, amorphous silica, even at the high surface area concentration $\left(150 \times 10^{6} \mathrm{\mu m}^{2} / \mathrm{cm}^{2}\right)$ did not induce increased secretion of any of these mediators. However, amorphous silica induced a significant decrease in the amount of interleukin-15 (IL-15) detected in medium, and both cristobalite and amorphous silica caused significant decreases in the amounts of monocyte chemotactic protein-1 (MCP-1; MCAF) secreted by BEAS 2B cells. Possible roles of IL-12 and IL-15 have been addressed in mouse inhalation models of silicosis [53]. However, it appears that innate immunity (as opposed to adaptive responses) plays a much stronger role in the development of silicosis [54], suggesting that IL-12 may have a less likely role in silicainduced disease.

It has been shown by others that crystalline silica particles induce expression and secretion of IL- 6 and IL-8 [21,45-49], potent mediators promoting acute phase responses and inflammation in lung diseases [55-58], and thus are implicated in silicosis [59]. RANTES and MCP-1/MCAF are secreted mediators associated with recruitment of monocytes, lymphocytes, and granulocytes [60]. Increased levels of RANTES and MCP-1/ MCAF expression also have been reported in alveolar type II cells exposed to crystalline silica [45], though increased expression of MCP-1 was seen early and had nearly diminished by 24 hours. Our studies show decreased levels of MCP-1/MCAF in medium of both crystalline and amorphous silica exposed BEAS 2B cells. The decreased levels of secreted MCP-1/MCAF may indicate a mechanism of lung defense or possibly an autocrine stimulation/negative feedback loop. In contrast, G-CSF is an extremely strong potentiator of neutrophilic response and recruitment (as reviewed in [61]), and is implicated in development of inflammation and pulmonary fibrosis [19].

In addition to modulators of inflammation, the proliferative and angiogenic factors, bFGF, VEGF and PDGF$\mathrm{BB}$ were released from BEAS $2 \mathrm{~B}$ cells exposed to cristobalite silica. PDGF-BB, a promoter of angiogenesis and cell proliferation, is implicated in silicosis and other pneumoconioses [62,63], and its expression may correlate with disease progression. Increased levels of serum VEGF are also observed in patients with idiopathic pulmonary fibrosis (IPF) [64]. In contrast, VEGF derived from myeloid cells is anti-fibrotic in a mouse model of pulmonary fibrosis [65]. Perhaps the cell of origin or location of VEGF secretion or the concentration of VEGF plays pivotal roles in the development and progression of pulmonary fibrosis.

Our data, consistent with other studies using crystalline silica in bronchial epithelial cells, shows that epithelial cells also have the ability to secrete bFGF in response to crystalline silica $[66,67]$. However, our study shows that crystalline silica as opposed to amorphous silica particles selectively induced bFGF secretion. This may indicate an autocrine or paracrine role of epithelial cell-derived bFGF in promoting fibrotic disease as it has been shown that bFGF promotes fibroblast proliferation in a transforming growth factor- $\beta$ (TGF- $\beta$ ) model of epithelial-mesenchymal transition $[68,69]$ and in the development and progression of interstitial pulmonary fibrosis [70]. Additionally, it has been shown that bFGF is associated with mast cells in human silicotic lungs [71].

Taken together, a number of pro-inflammatory, proliferative and angiogenic factors are released from lung epithelial cells, which are initial target cells in silicainduced disease. How these factors may interact with and regulate the airway environment is crucial in delineation of the role the epithelium plays in initiation and progression of silica-induced fibrosis. In addition, production and secretion of proliferative and angiogenic mediators may play a role in the potential carcinogenic effects of crystalline silica, by inducing excessive cell proliferation.

\section{Assessment of cell viability and gene expression induced by silica particles in primary human bronchial epithelial cells (NHBE)}

NHBE cells were used to confirm results from experiments with BEAS $2 \mathrm{~B}$ cells as these cells are primary as opposed to immortalized human bronchial epithelial cells and may be more responsive to particles. Figure 6 shows changes in cell viability and gene expression in primary NHBE cells by cristobalite and amorphous silica particles. When compared to BEAS $2 \mathrm{~B}$ cells, NHBE cells were more sensitive to the toxicity of silica particles. After $24 \mathrm{~h}$, both types of silica particles at 15, 75 and $150 \times 10^{6} \mu \mathrm{m}^{2} / \mathrm{cm}^{2}$ caused between $25-46 \%$ loss of viable cells (Figure 6A). Although particle exposures induced significant $(\mathrm{p}<0.05)$ decreases in the percentage of viable cells compared to unexposed controls, no significant differences were observed between toxicity of cristobalite vs. amorphous silica at equal surface area concentrations. Based on these results, we chose to expose NHBE cells to cristobalite silica at the lowest (15) and a higher (75) surface area concentration and 


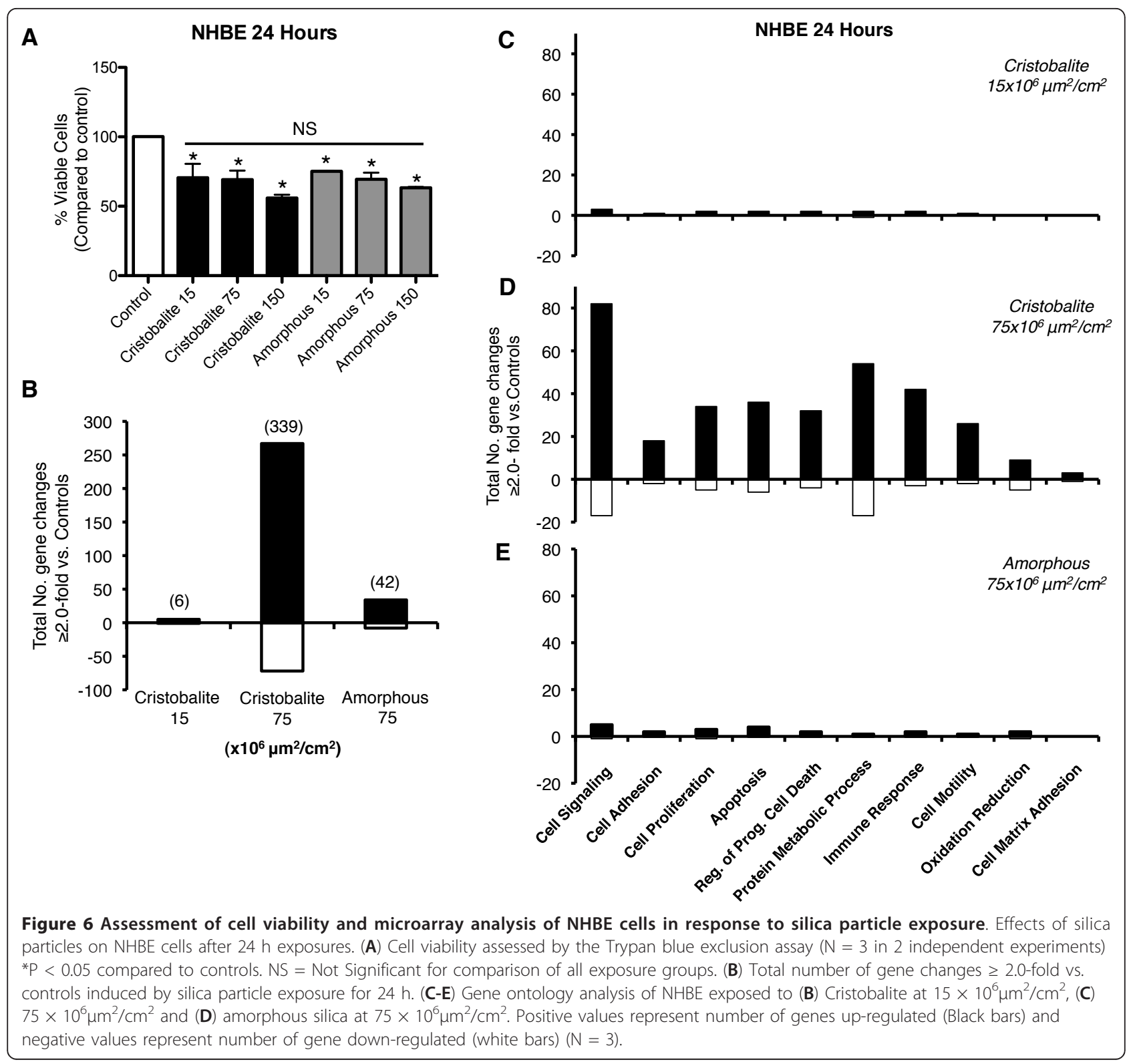

amorphous silica at $75 \times 10^{6} \mu \mathrm{m}^{2} / \mathrm{cm}^{2}$ in microarray analyses. Cristobalite at $15 \times 10^{6} \mathrm{\mu m}^{2} / \mathrm{cm}^{2}$ induced only 6 significant gene changes, though at the higher dose $\left(75 \times 10^{6} \mu \mathrm{m}^{2} / \mathrm{cm}^{2}\right), 339$ significant changes were detected. Interestingly, this is nearly the same number of significant changes (333) induced in BEAS 2B cells at the same exposure concentration (Figure $3 \mathrm{~A}$ ). In addition, amorphous silica at $75 \times 10^{6} \mu \mathrm{m}^{2} / \mathrm{cm}^{2}$, (i.e. half the dose used in BEAS 2B cells) (Figure 3A), produced only 42 significant changes.

Gene ontology analysis of the gene expression alterations in NHBE cells exposed to silica particles was performed to compare the trends seen in BEAS $2 \mathrm{~B}$ cells and to allow examination of similarities and differences between cells (Figure 6C-E, Additional file 3). The gene expression pattern of NHBE cells exposed to cristobalite or amorphous silica particles followed nearly the same patterns of expression with most gene changes categorized in the realms of cell signaling and proliferation, apoptosis, protein metabolic process and immune response.

Table 3 presents the top 10 genes up and down-regulated by cristobalite and amorphous silica particles in NHBE cells. IL8, at the top of this list, was up-regulated by cristobalite 4.37 and 28.47 -fold at 15 and $75 \times$ $10^{6} \mathrm{~mm}^{2} / \mathrm{cm}^{2}$ respectively. However, there was no increase in expression by amorphous silica particles. Interestingly, TXNIP was up-regulated by both 
Table 3 Top 10 genes affected by $24 \mathrm{~h}$ exposure to silica particles in NHBE

\begin{tabular}{|c|c|c|c|}
\hline \multirow[t]{3}{*}{ Gene Name (Abbreviation) } & \multicolumn{3}{|c|}{ Fold Change $^{a}$} \\
\hline & \multicolumn{2}{|c|}{ Cristobalite } & \multirow{2}{*}{$\begin{array}{c}\text { Amorphous } \\
75^{\mathrm{b}}\end{array}$} \\
\hline & $15^{b}$ & $75^{\mathrm{b}}$ & \\
\hline \multicolumn{4}{|l|}{ Up-regulated $\Delta$} \\
\hline Interleukin 8 (IL8) & 4.37 & 28.47 & NC \\
\hline Baculoviral IAP repeat-containing 3 (BIRC3) & 2.02 & 19.81 & NC \\
\hline BCL2-related protein A1 (BCL2A1) & NC & 19.27 & NC \\
\hline Tumor necrosis factor, alpha-induced protein 3 (TNFAIP3) & 2.33 & 17.11 & NC \\
\hline Interleukin 1 family, member 9 (IL1F9) & NC & 14.14 & NC \\
\hline GTP binding protein over expressed in skeletal muscle (GEM) & NC & 12.92 & NC \\
\hline CD83 molecule (CD83) & NC & 11.47 & NC \\
\hline Transcribed locus, strongly similar to NP_006463.2 thioredoxin interacting protein & NC & 11.09 & 27.95 \\
\hline Inhibin, beta A (INHBA) & NC & 10.25 & NC \\
\hline Thioredoxin interacting protein (TXNIP) & NC & 9.74 & 31.14 \\
\hline Heat shock 70 kDa protein 1A (HSPA1A) & 2.01 & 7.56 & 2.57 \\
\hline Crystallin, mu (CRYM) & NC & 4.97 & 2.35 \\
\hline G0/G1 switch 2 (G0S2) & NC & 3.51 & 3.12 \\
\hline Transcribed locus (BF4328873) & NC & NC & 2.73 \\
\hline Calcium binding tyrosine-(Y)-phosphorylation regulated (CABYR) & NC & 2.51 & 2.55 \\
\hline Non-protein coding RNA 84 (NCRNA00084) & NC & NC & 2.53 \\
\hline Sarcoglycan, gamma (35 kDa dystrophin-associated glycoprotein) (SGCG) & NC & NC & 2.50 \\
\hline Cytoplasmic FMR1 interacting protein 2 (CYFIP2) & NC & NC & 2.48 \\
\hline \multicolumn{4}{|l|}{ Down-regulated $\mathbf{v}$} \\
\hline Sulfatase (SULF1) & NC & 3.59 & NC \\
\hline Peroxisome proliferator-activated receptor gamma, coactivator 1 alpha (PPARGC1A) & NC & 3.52 & NC \\
\hline Solute carrier family 38, member 4 (SLC38A4) & NC & 3.43 & NC \\
\hline Amyotrophic lateral sclerosis 2 (juvenile) chromosome region, candidate 8 (ALS2CR8) & NC & 3.18 & 2.00 \\
\hline Growth arrest-specific 1 (GAS1) & NC & 2.84 & NC \\
\hline Hexokinase 2 (HK2) & NC & 2.69 & NC \\
\hline F-box protein 9 (FBXO9) & NC & 2.68 & NC \\
\hline Hairy/enhancer-of-split related with YRPW motif 1 (HEY1) & NC & 2.62 & NC \\
\hline CDNA FLJ37852 fis, clone BRSSN2014513 & NC & 2.61 & NC \\
\hline Growth hormone receptor (GHR) & NC & 2.59 & NC \\
\hline Solute carrier family 16, member 7 (monocarboxylic acid transporter 2) (SLC16A7) & NC & 2.50 & NC \\
\hline Transglutaminase 3 (E polypeptide, protein-glutamine-gamma-glutamyltransferase) (TGM3) & 2.13 & NC & NC \\
\hline Follistatin (FST) & NC & NC & 2.43 \\
\hline Homo sapiens clone FLB9440 PRO2550 mRNA, complete cds & NC & 2.32 & 2.18 \\
\hline Ribonucleotide reductase M2 polypeptide (RRM2) & NC & NC & 2.12 \\
\hline PPPDE peptidase domain containing 1 (PPPDE1) & NC & 2.23 & 2.06 \\
\hline
\end{tabular}

Top 10 genes in NHBE cells up and down-regulated by 24-hour exposure to cristobalite silica at 15 and $75 \times 10^{6} \mu \mathrm{m}^{2} / \mathrm{cm}^{2}$ and amorphous silica particles at $75 \times$ $10^{6} \mathrm{\mu m}^{2} / \mathrm{cm}^{2}$.

${ }^{\text {a }}$ Fold change (mRNA) expression $(p<0.05)$ cut-off $\geq 2.0$-fold compared to controls $(n=3)$.

b Silica particle concentrations: $\left(\times 10^{6} \mu \mathrm{m}^{2} / \mathrm{cm}^{2}\right)$

$\mathrm{NC}=$ No Change

cristobalite and amorphous silica by 9.74-fold and 31.14fold respectively. This protein binds to NLRP3 and promotes inflammasome activation in response to oxidative stress [72]. Other genes of interest in this table include BIRC3, BCL2A1 and TNFAIP3, which are involved in regulation of apoptosis. When comparing the top 10 genes altered in expression by crystalline silica particles in BEAS 2B and NHBE cells, only one gene, Solute carrier family 38, member 4 (SLC38A4), a sodiumdependent amino acid symporter, is common to both cells (within the top 10). However, when all gene expression changes by cristobalite silica were compared in BEAS 2B and NHBE cells (Table 4), we found 60 genes commonly altered (57 up-regulated and 3 downregulated). Of these 60 genes, 36 were altered in both cell types at the same surface area concentration $(75 \times$ 
Table 4 Genes commonly affected by $24 \mathrm{~h}$ cristobalite exposure in NHBE and BEAS 2B cells

\begin{tabular}{|c|c|c|c|}
\hline \multirow{2}{*}{$\begin{array}{l}\text { Gene Name (Abbreviation) } \\
\text { Cell Type } \\
\text { (Cristobalite) }^{\text {b }}\end{array}$} & \multicolumn{3}{|c|}{ Fold Change $^{a}$} \\
\hline & $\begin{array}{l}\text { NHBE } \\
(75)\end{array}$ & $\begin{array}{c}\text { BEAS 2B } \\
(75)\end{array}$ & $\begin{array}{c}\text { BEAS 2B } \\
(150)\end{array}$ \\
\hline \multicolumn{4}{|l|}{ Up-regulated $\triangle$} \\
\hline Interleukin 8 (IL8) & 28.47 & 2.12 & 2.65 \\
\hline BCL2-related protein A1 (BCL2A1) & 19.27 & NC & 3.08 \\
\hline Tumor necrosis factor, alpha-induced protein 3 (TNFAIP3) & 17.11 & 2.23 & 2.95 \\
\hline GTP binding protein overexpressed in skeletal muscle (GEM) & 12.92 & NC & 2.13 \\
\hline Inhibin, Beta A (INHBA) & 10.25 & 2.24 & 3.62 \\
\hline Interleukin 24 (IL24) & 7.62 & 3.88 & 8.54 \\
\hline Heat shock 70 kDa protein 1A (HSPA1A) & 7.56 & NC & 2.34 \\
\hline Chemokine (C-X-C motif) ligand 3 (CXCL3) & 7.42 & NC & 2.42 \\
\hline TNF receptor-associated factor 1 (TRAF1) & 7.30 & 2.86 & 4.22 \\
\hline Radical S-adenosyl methionine domain containing 2 (RSAD2) & 6.92 & 5.45 & 23.25 \\
\hline Early growth response 1 (EGR1) & 6.72 & 2.65 & 4.63 \\
\hline Coiled-coil domain containing 85B (CCDC85B) & 6.46 & 3.44 & 6.11 \\
\hline FOS-like antigen 1 (FOSL1) & 5.80 & 2.47 & 3.18 \\
\hline Early growth response 3 (EGR3) & 5.31 & NC & 2.65 \\
\hline Jun oncogene (JUN) & 4.99 & NC & 2.00 \\
\hline Matrix metallopeptidase 1, interstitial collagenase (MMP1) & 4.99 & 16.12 & 44.68 \\
\hline 2'-5'-oligoadenylate synthetase-like (OASL) & 4.20 & NC & 18.85 \\
\hline CAMP responsive element binding protein 5 (CREB5) & 3.87 & 3.25 & 4.10 \\
\hline Transcribed locus, strongly similar to NP_000337.1 transcription factor SOX9 (SOX9) & 3.84 & NC & 2.12 \\
\hline Interferon induced with helicase C domain 1(IFIH1) & 3.79 & NC & 3.86 \\
\hline Heat shock 70 kDa protein 6 (HSP70B') & 3.70 & 4.08 & 14.39 \\
\hline Kynureninase (L-kynurenine hydrolase) (KYNU) & 3.66 & NC & 2.19 \\
\hline Prostaglandin-endoperoxide synthase 2 (PTGS2) & 3.56 & NC & 2.54 \\
\hline Superoxide dismutase 2, mitochondrial (SOD2) & 3.53 & NC & 2.86 \\
\hline Interleukin 1 receptor-like 1 (IL1RL1) & 3.52 & 2.89 & 5.36 \\
\hline Interferon-induced protein with tetratricopeptide repeats 1 (IFIT1) & 3.45 & 6.01 & 16.26 \\
\hline Interferon-induced protein 44 (IFI44) & 3.36 & 7.51 & 19.90 \\
\hline Nuclear receptor subfamily 1 , group D, member 1 (NR1D1) & 3.24 & 3.01 & 4.72 \\
\hline Interferon stimulated exonuclease gene 20 kDa (ISG20) & 3.21 & NC & 2.48 \\
\hline Plasminogen activator, urokinase receptor (PLAUR) & 3.14 & NC & 2.35 \\
\hline Transmembrane protein 40 (TMEM40) & 3.06 & NC & 4.15 \\
\hline Distal-less homeobox 2 (DLX2) & 2.99 & 2.34 & 3.78 \\
\hline Niacin receptor 2 (NIACR2 OR GPR109B) & 2.87 & 3.14 & NC \\
\hline Human 285 ribosomal RNA gene, complete cds. (RNA28S1) & 2.86 & NC & 2.21 \\
\hline Histone deacetylase 9 (HDAC9) & 2.84 & 3.24 & NC \\
\hline 2'-5'-oligoadenylate synthetase 1, 40/46 kDa (OAS1) & 2.83 & NC & 20.53 \\
\hline Nuclear receptor subfamily 4, group A, member 3 (NR4A3) & 2.79 & 2.58 & 3.49 \\
\hline Oxidative stress induced growth inhibitor 1 (OSGIN1) & 2.79 & NC & 2.48 \\
\hline Smoothelin (SMTN) & 2.74 & 2.38 & 2.72 \\
\hline Heme oxygenase (decycling) 1 (HMOX1) & 2.69 & NC & 2.57 \\
\hline Basic helix-loop-helix family, member e41 (BHLHE41) & 2.64 & NC & 2.34 \\
\hline ADAM metallopeptidase domain 8 (ADAM8) & 2.62 & $\mathrm{NC}$ & 2.08 \\
\hline Crystallin, alpha B (CRYAB) & 2.58 & 2.26 & 2.67 \\
\hline Colony stimulating factor 2 (granulocyte-macrophage) (CSF2) & 2.53 & 4.20 & 7.37 \\
\hline Calcium binding tyrosine-(Y)-phosphorylation regulated (CABYR) & 2.51 & NC & 2.19 \\
\hline Chromosome 1 open reading frame 38 (C1orf38) & 2.44 & NC & 3.04 \\
\hline 2'-5'-oligoadenylate synthetase 3, 100 kDa (OAS3) & 2.29 & 2.41 & 3.84 \\
\hline Sprouty homolog 4 (Drosophila) (SPRY4) & 2.26 & 2.98 & 4.64 \\
\hline Dual specificity phosphatase 5 (DUSP5) & 2.23 & 2.02 & 2.61 \\
\hline
\end{tabular}


Table 4 Genes commonly affected by $24 \mathrm{~h}$ cristobalite exposure in NHBE and BEAS 2B cells (Continued)

\begin{tabular}{|c|c|c|c|}
\hline Ring finger protein 39 (RNF39) & 2.22 & 2.47 & 3.65 \\
\hline Leukemia inhibitor factor (Cholinergic differentiation factor) (LIF) & 2.21 & 2.96 & 4.73 \\
\hline Sphingosine kinase 1 (SPHK1) & 2.11 & 3.20 & 4.88 \\
\hline Interleukin 6 (Interferon, beta 2) (IL6) & 2.10 & 2.12 & 2.59 \\
\hline Interleukin 1, alpha (IL1A) & 2.09 & 3.97 & 6.17 \\
\hline FBJ murine osteosarcoma viral oncogene homolog B (FOSB) & 2.07 & 3.65 & 6.37 \\
\hline Serpin peptidase inhibitor, clade B (ovalbumin), member 2 (PAI2) & 2.04 & 2.16 & 4.33 \\
\hline DEAD (Asp-Glu-Ala-Asp) box polypeptide 60 (DDX60) & 2.02 & 2.26 & 5.01 \\
\hline \multicolumn{4}{|l|}{ Down-regulated $\mathbf{v}$} \\
\hline Sulfatase 1 (SULF1) & 3.59 & 2.01 & 2.10 \\
\hline Peroxisome proliferator-activated receptor gamma, coactivator 1 alpha (PPARGC1A) & 3.52 & 2.85 & 3.75 \\
\hline Chromosome 5 open reading frame 13 (C5orf13) & 2.05 & NC & 2.21 \\
\hline
\end{tabular}

$10^{6} \mathrm{\mu m}^{2} / \mathrm{cm}^{2}$ ) and 57 were commonly altered in NHBE cells at $75 \times 10^{6} \mu \mathrm{m}^{2} / \mathrm{cm}^{2}$ vs. BEAS $2 \mathrm{~B}$ at $150 \times 10^{6} \mu \mathrm{m}^{2} /$ $\mathrm{cm}^{2}$. It should be noted that 60 genes may not appear to be a large portion of over 300 genes altered by cristobalite. However, the majority of these genes have strong connections with potential mechanisms of crystalline silica-induced disease, namely inflammation, fibrotic processes, as well as cell proliferation/anti-apoptosis (carcinogenesis).

Within this list of commonly affected genes there are a number of transcription factors, cytokines/chemokines and receptors, oxidative stress-related, and genes related to the regulation of apoptosis, proliferation, cell signaling and ECM breakdown. The transcription factors, FOSL1 (fra-1), FOSB and, JUN, members of the AP-1 complex family, as well as CREB5, which can also interact with jun family members, were up-regulated by cristobalite in both cell lines. The AP-1 transcription factor complex appears to play a major role in cellular response to crystalline silica [50]. In addition, the transcriptional regulators EGR1 and EGR3 were induced by cristobalite silica.

A number of pro-inflammatory mediators were also increased at the mRNA level by cristobalite in NHBE and BEAS $2 \mathrm{~B}$ cells including, IL1A, IL6, IL8, IL24, CXCL3, (MIP-2 $\beta$ ), CSF2 (GM-CSF) and the IL1RL1. Some of these genes (ILIA, IL1RL1) and their proteins are involved in regulation and activity of the NALP3 inflammasome, a signaling complex that responds to "danger signals" and promotes an inflammatory response after addition of silica to human THP-1 macrophages [73]. In line with the hypothesis that oxidative stress mediates inflammasome activity by silica, oxidative-stress response-genes, PTGS2 (COX2), SOD2 (MnSOD), HMOX1 and OSGIN1 were also up-regulated by cristobalite in NHBE and BEAS $2 \mathrm{~B}$ cells. These findings also reinforce the observations that inflammation and oxidative stress are two of the driving forces in silica-induced disease mechanisms [74]. Inflammation and oxidative stress create an imbalanced cellular environment, with cellular injury, and death or cell proliferation. These mechanisms may contribute to airway remodeling and indirect mechanisms of carcinogenicity, promoting a favorable microenvironment for both fibrosis and tumor formation.

A number of other genes were also altered in expression by cristobalite in both cell lines, including genes involved in ECM breakdown (MMP1 and PLAUR), genes involved in cell signaling regulation (HDAC9), and regulators of MAPK signaling (SPRY4 and DUSP5). Other genes are involved in anti-viral activity and interferon-response including, RSAD2, OAS1, OAS3, OASL, IFIH1, IFIT2, IFI44 and ISG20. Of those genes, IFIT1 and IFI44 were up-regulated in both cell types by amorphous silica particles as well.

\section{Conclusions}

Particulates, especially in the realm of nanotoxicology, are rapidly becoming a question of concern regarding health effects in occupational setting as well as in the environment. Our studies and a recent report in the literature [41] demonstrate that gene expression profiling in human lung epithelial cells in vitro can be used to determine the relative pathogenicity of potentially harmful particulates (i.e. crystalline silica and airborne particulate matter, respectively) as opposed to viability studies and metabolic testing. Changes in expression of genes related to inflammation, oxidative stress, and proliferation as well as the secretion of proinflammatory, angiogenic and proliferative cytokines and chemokines 
re-emphasize the complex reactions of the lung epithelium to crystalline silica particles and their relation to development of fibrosis [12].

Our studies compared two particles of the same chemical make up $\left(\mathrm{SiO}_{2}\right)$, but of different habit (i.e. crystalline vs. amorphous). The responses observed suggest that the crystallinity of cristobalite may dictate early molecular responses as well as dissolution of particles over time in the lung. Moreover, we show that the magnitude and patterns of differential gene expression by crystalline silica are similar in both BEAS $2 \mathrm{~B}$ and NHBE cells, suggesting that immortalized and established epithelial cell lines can be used as in vitro models to predict the pathogenicity of potentially harmful respirable particulates as opposed to expensive and time-consuming isolation of human primary cells and animal inhalation studies.

\section{Methods}

\section{Human Bronchial Epithelial Cell Cultures}

Non-tumorigenic human bronchial epithelial cells (Ad12-SV40 immortalized) BEAS 2B (ATCC, Manassas, VA) were grown and maintained in DMEM/F12 50:50 media containing 10\% Fetal Bovine Serum (FBS) (CellGro ${ }^{\circledR}$ Mediatech inc, Manassas, VA), with penicillin (50 units $/ \mathrm{ml})$, streptomycin $(100 \mu \mathrm{g} / \mathrm{ml})$ (Invitrogen, Carlsbad, CA), hydrocortisone $(100 \mu \mathrm{g} / \mathrm{ml})$, insulin $(2.5 \mu \mathrm{g} /$ $\mathrm{ml})$, transferrin $(2.5 \mu \mathrm{g} / \mathrm{ml})$ and selenium $(2.5 \mu \mathrm{g} / \mathrm{ml})$ (Sigma, St. Louis, MO). BEAS $2 \mathrm{~B}$ cells culture flasks and plates (BD, Franklin Lakes, NJ) were pre-coated with a mixture of fibronectin (Sigma, St. Louis, MO) (0.01 mg/ $\mathrm{ml})$, bovine collagen type I $(0.03 \mathrm{mg} / \mathrm{ml})$ (Invitrogen, Carlsbad, CA) and bovine serum albumin $(0.01 \mathrm{mg} / \mathrm{ml})$ (Sigma, St. Louis, MO), dissolved in DMEM/F12 media for 24 hours at $37^{\circ} \mathrm{C}$ prior to culturing cells. Prior to exposures, medium was aspirated and replaced with a reduction medium containing $0.5 \%$ FBS. Primary normal human bronchial epithelial cells (NHBE-17917) were purchased from Lonza, Clonetics ${ }^{\circledR}$. NHBE cells were cultured and maintained in $\mathrm{BEGM}^{\circledR}$ and with Reagentpack $^{\mathrm{TM}_{\mathrm{M}}}$ subculture reagents (Trypsin/EDTA, Trypsin Neutralizing Solution and Hepes-buffered saline solution), all purchased from Lonza, Clonetics ${ }^{\circledR}$. (Switzerland) were used for subculture following manufacturers protocol.

\section{Synthesis, Characterization, and Determination of Surface Areas of Silica Particles}

The amorphous silica microparticles were prepared according to the procedure of De et al [75] in the Department of Chemistry, University of Vermont, Burlington, VT, USA. Briefly, tetraethylorthosilicate (32.0 g, $0.143 \mathrm{~mol})$ was combined with water $(11.0 \mathrm{~g}, 0.611 \mathrm{~mol})$ and stirred rapidly $(600 \mathrm{rpm})$ to form an emulsion. To this emulsion was rapidly added glacial acetic acid (36.8 g, $0.643 \mathrm{~mol}$ ), and stirring was continued for $60 \mathrm{~s}$, at which point stirring was terminated. The mixture was then allowed to sit quiescently for $45 \mathrm{~min}$. Afterward the particles were filtered and washed extensively with water $(5 \mathrm{~mL} \times 4)$ and ethanol $(5 \mathrm{~mL} \times 3)$. After air-drying for several hours, the particles were dried overnight under vacuum, then particles were calcined at $550^{\circ} \mathrm{C}$ for 12 hours under air. Finally, the particles were ground with a mortar and pestle to yield a freely-flowing, white powder ( $4.8 \mathrm{~g}$, 56\% yield). Samples were mounted for SEM by dusting onto carbon tape applied to aluminum sample stubs. They were then sputter coated with $\mathrm{Pd} /$ $\mathrm{Au}$ for 3.5 minutes in a Polaron sputter coater (Model 5100). Specimens were then examined with a JSM 6060 scanning electron microscope (JEOL USA, Inc., Peabody, MA) operating at an accelerating voltage of $25 \mathrm{kV}$ and a working distance of $10 \mathrm{~mm}$. Size distribution was determined using SEM images by measuring the diameter of 300-400 silica particles (5 fields of view) using Metamorph offline software version 7.7.3 64 bit (Molecular Devices, Sunnyvale, CA). Cristobalite silica was examined by powder X-ray diffraction methods using a Rigaku MiniFlexII X-ray diffractometer. Rietveld analysis, as implemented in the Rigaku WPPF program, was undertaken with eight-second fixed time scans at $0.02^{\circ}$ steps from $10^{\circ}$ to $100^{\circ} 2 \theta$. For the scan, R $w p=10.94 \%$, modelled with $\alpha$-quartz and cristobalite. The quantitative analysis by Rietveld analysis yielded 95.5( \pm 0.03$) \%$ cristobalite, and 4.54(0.08)\% quartz. Surface area of particles was determined by BET nitrogen adsorption analysis. Nitrogen adsorption and desorption isotherms were obtained on a Micromeritics TriStar instrument after samples were degassed overnight under vacuum. Surface areas were measured using the BET method, and pore size distributions were calculated from a modified KJS method using the adsorption branch [76-78].

\section{Particle Exposure to Cells}

Prior to exposure, particles were weighed in scintillation vials and placed under UV light overnight to be sterilized. Particles were then submerged in Hanks' Balanced Salt Solution (HBSS) (CellGro ${ }^{\circledR}$ Mediatech inc, Manassas, VA) at (1.0-2.0 mg/ml). Particle suspensions were sonicated in a waterbath sonicator for 15 minutes followed by being trichurated 5 times through a 22-gauge needle. Suspensions were then administered to cell culture plates and briefly shaken to assure dispersion of particles before they settle.

\section{Assessment of Cell Viability}

After $24 \mathrm{~h}$, cells were collected by detatching with $0.25 \%$ Trypsin (Invitrogen, Carlsbad, CA) solution in HBSS, and a final volume of $1.5 \mathrm{ml}(0.5 \mathrm{ml}$ trypsin solution + 
$1.0 \mathrm{ml}$ 10\% FBS medium was collected on ice. This solution was diluted $1: 5$ in a solution of $0.4 \%$ trypan blue (MP Biomedicals, Solon, $\mathrm{OH}$ ), which is a dye retained by dead cells and excluded by viable cells and HBSS. After 5 min, unstained viable cells were counted using a hemocytometer to determine the total number of viable cells per dish and particle exposed groups were compared unexposed controls as described previously [79] For each group (particle type/concentration) $n=3$ and experiments were performed in triplicate (BEAS 2B) and duplicate (NHBE).

\section{Scanning Electron Microscopy}

For imaging of cristobalite silica and amorphous silica particles, 0.0029 or $0.0026 \mathrm{~g}$ was diluted to a final concentration of 1.45 and $1.3 \mu \mathrm{g} / \mathrm{ml}$ ( $4.0 \mathrm{ml}$ total volume), respectively, in a solution of $6 \%$ ethanol and $\mathrm{ddH}_{2} \mathrm{O}$ by serial dilution. Silica particle dilutions were filtered through a $0.4 \mu \mathrm{m}$ Nucleopore Track-Etch membrane (Fisher Scientific, Pittsburgh, PA) followed by a rinse with $1.0 \mathrm{ml} 100 \%$ ethanol and drying overnight. Half of the dried filter was adhered to a standard aluminum specimen stub with graphite point (Electron Microscope Sciences, Hatfield, PA) followed by sputter coating with gold and palladium using a Polaron sputter coater (Model 5100; Quorum Technologies, East Sussex, UK) Specimens were imaged and EDS analysis was performed using an INCA $350 \times$ Max detector and INCA Energy System software (Oxford Instruments, Concord, MA) by "point-analysis". BEAS 2B cells were grown on Thermonox plastic cover slips (Nalge Nunc International, Naperville, IL). Prior to seeding cells, cover slips were coated with fibronectin $(0.01 \mathrm{mg} / \mathrm{ml})$, bovine collagen type $\mathrm{I}(0.03 \mathrm{mg} / \mathrm{ml})$ and bovine serum albumin $(0.01 \mathrm{mg} / \mathrm{ml})$ dissolved in DMEM/F12 medium for $24 \mathrm{~h}$ at $37^{\circ} \mathrm{C}$. Cells were grown to near confluency and then put in reduction medium $(0.5 \%$ FBS $) 24 \mathrm{~h}$ prior to incubation with particles. Cells were exposed to silica particles for 2 and $24 \mathrm{~h}$ before fixation. Cells were fixed with $2 \%$ glutaraldehyde in $0.1 \mathrm{M}$ phosphate buffered saline (PBS) for $1 \mathrm{~h}$ at $4^{\circ} \mathrm{C}$. Samples then rinsed for $5 \mathrm{~min}$ in PBS $(3 \times)$ and then $(1 \times) 5$ minutes in $0.05 \mathrm{M}$ cacodylate buffer ( $\mathrm{pH} 7.2)$. Samples then post-fixed with $1 \%$ osmium tetroxide in $0.05 \mathrm{M}$ cacodylate buffer (pH7.2) for $1 \mathrm{~h}$ at room temperature, then rinsed $(3 \times)$ for $5 \mathrm{~min}$ in $0.05 \mathrm{M}$ cacodylate buffer. Samples immersed in $1 \%$ tannic acid in $0.05 \mathrm{M}$ cacodylate buffer for $1 \mathrm{~h}$ at room temperature and in the dark (covered with foil), rinsed $1 \times$ for $5 \mathrm{~min}$ in cacodylate buffer and $3 \times$ for $5 \mathrm{~min}$ in distilled water. Samples incubated with $0.5 \%$ uranyl acetate in distilled water for $1 \mathrm{hr}$ at room temperature in the dark (covered with foil), rinsed $3 \times$ for $5 \mathrm{~min}$ in distilled water, and stored in $0.05 \mathrm{M}$ cacodylate buffer at $4^{\circ}$ C. Cover slips were put in cylindrical holder and dehydrated in ethanol series: using 10 min changes in $35,50,70,85 \%$ up to $95 \%$ ethanol, then $(2 \times) 20 \mathrm{~min}$ changes in $95 \%$ ethanol, followed by three $15 \mathrm{~min}$ changes in anhydrous $100 \%$ ethanol. Samples were then critical-point dried and fixed to aluminium specimen mounts with carbon paint and dried overnight in a desiccator. Samples were then sputter-coated with gold and palladium in a Polaron sputter coater (Model 5100) and imaged on JSM-6060 scanning electron microscope (JEOL USA, Inc. Peabody, MA).

\section{RNA Isolation and Microarray Profiling}

Total RNA was prepared using an RNeasy ${ }^{\circledR}$ Plus Mini Kit according to the manufacturers' protocol (Qiagen, Valencia, CA), as published previously [80]. All procedures were performed by the Microarray analysis core facility of the Vermont Genetics Network (VGN) using a standard Affymetrix protocol as described previously [80,81]. GeneChip ${ }^{\circledR}$ Human Genome U133A 2.0 arrays (Affymetrix, Santa Clara, CA) targeting 18,400 human transcripts were scanned twice (Hewlett-Packard GeneArray Scanner), the images overlaid, and the average intensities of each probe cell compiled. Microarray data were analyzed using GeneSifter software (VizX Labs, Seattle, WA). This program used a t-test for pair- wise comparison and a Benjamini-Hochberg test for false discovery rate (FDR 5\%) to adjust for multiple comparisons. A 2-fold cutoff limit was used for analysis (only genes up or down-regulated $\geq 2$.0-fold vs. unexposed controls)

\section{Quantitative Real-time Polymerase Chain Reaction (qRT- PCR)}

Total RNA $(1 \mu \mathrm{g})$ was reverse-transcribed with random primers using the AMV Reverse Transcriptase kit (Promega, Madison, WI) according to the recommendations of the manufacturer, as described previously [80]. All Taqman ${ }^{\circledR}$ qRT-PCR was performed using Assays-OnDemand $^{\mathrm{TM}}$ primer and probe sets used for Applied Biosystems (Foster City, CA) and performed as described previously [31].

\section{Bio-Plex Analysis of Cytokines and Chemokines in Medium of BEAS 2B Cells}

To quantify cytokine, chemokine, and growth factor levels in conditioned medium of BEAS $2 \mathrm{~B}$ cells exposed to silica particles, a multiplex suspension protein array was performed using the Bio-Plex ${ }^{\circledR}$ protein array system and a human cytokine 27-plex panel (Bio-Rad, Hercules, CA), as previously described [80]. A sample of $0.05 \%$ FBS medium alone was also run to account for background levels of secreted proteins. Data are expressed as pg of cytokine $/ \mathrm{mL}$ of conditioned medium (mean \pm SEM), with $\mathrm{N}=3$ for each group. 


\section{Statistical Analyses}

Statistical analysis of results from cell viability and BioPlex analysis were evaluated by analysis of variance (ANOVA) using the Student Neuman-Keul's procedure for adjustment of multiple pair-wise comparisons between treatment groups. Significant differences in gene expression values determined by qRT-PCR were evaluated using a Student's t-test. Differences with $\mathrm{p}$ values $<0.05$ were considered statistically significant.

\section{Additional material}

\section{Additional file 1: SEM Imaging and EDS Analysis of Silica Particles.}

SEM images of filtered (A) cristobalite silica and (B) amorphous silica particles with respectful electron dispersive spectroscopy (EDS) spectra showing their identical chemical composition. Images are at a magnification of $1500 x$ and scale bars equal to $10 \mu \mathrm{m}$. Black arrows indicate the points analyzed by EDS "point-analysis", spectra represent points indicated. Silicon (Si) and oxygen (O) peaks of each particle type indicate both are pure silica particles. Gold (Au) and palladium (Pd) peaks are present due to the gold and palladium sputter-coating, carbon (C) is present because of graphite paint used to mount particle filters.

Additional File 2: Silica Particle Size Distrbution. Histograms represent size-distribution of cristobalite silica particles (A) and amorphous silica particles (B). Particles were filtered and imaged by SEM at 1000x magnification. The diameter of each particle was recorded using Metamorph $^{\mathbb{B}_{\oplus}}$, and 300-400 particles (5 fields/stub) were measured for each type of silica particle.

Additional file 3: Gene Ontology of BEAS 2B and NHBE Exposed to Silica Particles for $\mathbf{2 4} \mathrm{h}$ (\%Total/Category). Pie charts (A-F) represent gene ontology analysis of alterations in gene expression of BEAS $2 B$ cells (A-C) exposed to (A) cristobalite $75 \times 10^{6} \mu \mathrm{m}^{2} / \mathrm{cm}^{2}$, (B) cristobalite $150 \times$ $10^{6} \mathrm{\mu m}^{2} / \mathrm{cm}^{2}$ and (C) amorphous silica $150 \times 10^{6} \mathrm{\mu m}^{2} / \mathrm{cm}^{2}$. Gene ontology of NHBE cells (D-F) exposed to (D) cristobalite $15 \times 10^{6} \mathrm{\mu m}^{2} / \mathrm{cm}^{2}$, (E) cristobalite $75 \times 10^{6} \mathrm{\mu m}^{2} / \mathrm{cm}^{2}$ and amorphous silica $75 \times 10^{6} \mathrm{\mu m}^{2} / \mathrm{cm}^{2}$ Ten categories of interest were analyzed and charts represent the percent (\%) of total genes altered in each category for each exposure group.

\section{Acknowledgements}

This work was supported by an unrestricted grant from the Weijerhorst Foundation. The gene expression profiling was performed in the Vermont Genetics Network Microarray Facility through Grant Number P20 RR16462 from the INBRE Program of the National Center for Research Resources (NCRR), a component of the National Institutes of Health (NIH). Its contents are solely the responsibility of the authors and do not necessarily represent the official views of NCRR or NIH. QRT-PCR was performed in the VT Cancer Center DNA Analysis Facility and was supported by Vermont Cancer Center, Lake Champlain Cancer Research Organization, and the UVM College of Medicine. We would also like to thank the Microscopy Imaging Center at the University of Vermont (Burlington, VT) for assistance with scanning electron microscopy and electron dispersion spectroscopy. We thank John Hughes, Ph.D, for XRD analysis performed in the Dept. of Geology at the University of Vermont that was funded by and NSF grant: NSF-EAR-0922961, and Gregory Druschel, Ph.D for input on mineral characterization.

\section{Author details}

'Department of Pathology, University of Vermont College of Medicine, 89 Beaumont Avenue, Burlington, VT 05405, USA. ${ }^{2}$ Department of Respiratory Medicine, Maastricht University Medical Centre, Maastricht University, Maastricht, The Netherlands. ${ }^{3}$ Department of Chemistry, University of Vermont, Burlington, VT 05405, USA. ${ }^{4}$ Department of Medicine, University of Alabama at Birmingham School of Medicine, Birmingham, AL 35233, USA.
\end{abstract}

\section{Authors' contributions}

The study design was constructed by TNP, BTM, NLR and EFW. Cell culture, RNA isolation, medium collection, CDNA preparation was performed by TNP and PMP. TNP and AS performed the majority of data analysis. JLS and CCL synthesized amorphous silica particles and determined surface area properties of particles. SLM performed SEM. CS performed Bio-Plex analysis cell supernatants. TNP and BTM drafted the manuscript. All authors have read and approved the final manuscript.

\section{Competing interests}

The authors declare that they have no competing interests.

Received: 15 August 2011 Accepted: 2 February 2012

Published: 2 February 2012

\section{References}

1. Mundt KA, Birk T, Parsons W, Borsch-Galetke E, Siegmund K, Heavner K, Guldner K: Respirable crystalline silica exposure-response evaluation of silicosis morbidity and lung cancer mortality in the German porcelain industry cohort. J Occup Environ Med 2011, 53:282-289.

2. Cox LA Jr: An Exposure-Response Threshold for Lung Diseases and Lung Cancer Caused by Crystalline Silica. Risk Anal 2011.

3. Rimal B, Greenberg AK, Rom WN: Basic pathogenetic mechanisms in silicosis: current understanding. Curr Opin Pulm Med 2005, 11:169-173.

4. Straif K, Benbrahim-Tallaa L, Baan R, Grosse Y, Secretan B, El Ghissassi F, Bouvard V, Guha N, Freeman C, Galichet L, Cogliano V: A review of human carcinogens-part C: metals, arsenic, dusts, and fibres. Lancet Oncol 2009, 10:453-454.

5. Gamble JF: Crystalline silica and Lung cancer: A critical review of the occupational epidemiology literature of exposure-response studies testing this hypothesis. Crit Rev Toxicol 2011, 41:404-465.

6. Cassidy A, t Mannetje A, van Tongeren M, Field JK, Zaridze D, Szeszenia-Dabrowska N, Rudnai P, Lissowska J, Fabianova E, Mates D, et al: Occupational exposure to crystalline silica and risk of lung cancer: a multicenter case-control study in Europe. Epidemiology 2007, 18:36-43.

7. Finkelstein MM: Silica, silicosis, and lung cancer: a risk assessment. Am J Ind Med 2000, 38:8-18.

8. Flanagan ME, Seixas N, Majar M, Camp J, Morgan M: Silica dust exposures during selected construction activities. AlHA J (Fairfax, Va) 2003, 64:319-328.

9. Rappaport SM, Goldberg M, Susi P, Herrick RF: Excessive exposure to silica in the US construction industry. Ann Occup Hyg 2003, 47:111-122.

10. Cocco P: The long and winding road from silica exposure to silicosis and other health effects. Occup Environ Med 2003, 60:157-158.

11. Absher MP, Trombley L, Hemenway DR, Mickey RM, Leslie KO: Biphasic cellular and tissue response of rat lungs after eight-day aerosol exposure to the silicon dioxide cristobalite. Am J Pathol 1989, 134:1243-1251.

12. Mossman BT, Churg A: Mechanisms in the pathogenesis of asbestosis and silicosis. Am J Respir Crit Care Med 1998, 157:1666-1680.

13. Riva DR, Magalhaes CB, Lopes AA, Lancas T, Mauad T, Malm O, Valenca SS, Saldiva PH, Faffe DS, Zin WA: Low dose of fine particulate matter (PM2.5) can induce acute oxidative stress, inflammation and pulmonary impairment in healthy mice. Inhal Toxicol 2011, 23:257-267.

14. Carter JM, Driscoll KE: The role of inflammation, oxidative stress, and proliferation in silica-induced lung disease: a species comparison. J Environ Pathol Toxicol Oncol 2001, 20(Suppl 1):33-43.

15. Donaldson K, Stone V, Duffin R, Clouter A, Schins R, Borm P: The quartz hazard: effects of surface and matrix on inflammogenic activity. J Environ Pathol Toxicol Oncol 2001, 20(Suppl 1):109-118.

16. Knaapen AM, Albrecht C, Becker A, Hohr D, Winzer A, Haenen GR, Borm PJ, Schins RP: DNA damage in lung epithelial cells isolated from rats exposed to quartz: role of surface reactivity and neutrophilic inflammation. Carcinogenesis 2002, 23:1111-1120.

17. Porter DW, Ramsey D, Hubbs AF, Battelli L, Ma J, Barger M, Landsittel D, Robinson VA, McLaurin J, Khan A, et al: Time course of pulmonary response of rats to inhalation of crystalline silica: histological results and biochemical indices of damage, lipidosis, and fibrosis. J Environ Pathol Toxicol Oncol 2001, 20(Suppl 1):1-14. 
18. Rao KM, Porter DW, Meighan T, Castranova V: The sources of inflammatory mediators in the lung after silica exposure. Environ Health Perspect 2004. 112:1679-1686.

19. Velan GM, Kumar RK, Cohen DD: Pulmonary inflammation and fibrosis following subacute inhalational exposure to silica: determinants of progression. Pathology 1993, 25:282-290.

20. Warheit DB, McHugh TA, Hartsky MA: Differential pulmonary responses in rats inhaling crystalline, colloidal or amorphous silica dusts. Scand J Work Environ Health 1995, 21(Suppl 2):19-21.

21. Ovrevik J, Lag M, Schwarze P, Refsnes M: p38 and Src-ERK1/2 pathways regulate crystalline silica-induced chemokine release in pulmonary epithelial cells. Toxicol Sci 2004, 81:480-490.

22. Ramos-Nino ME, Haegens A, Shukla A, Mossman BT: Role of mitogenactivated protein kinases (MAPK) in cell injury and proliferation by environmental particulates. Mol Cell Biochem 2002, 234-235:111-118.

23. Albrecht C, Borm PJ, Adolf B, Timblin CR, Mossman BT: In vitro and in vivo activation of extracellular signal-regulated kinases by coal dusts and quartz silica. Toxicol Appl Pharmacol 2002, 184:37-45

24. Hubbard AK, Timblin CR, Rincon M, Mossman BT: Use of transgenic luciferase reporter mice to determine activation of transcription factors and gene expression by fibrogenic particles. Chest 2001, 120:24S-25S.

25. Hubbard AK, Timblin CR, Shukla A, Rincon M, Mossman BT: Activation of NF-kappaB-dependent gene expression by silica in lungs of luciferase reporter mice. Am J Physiol Lung Cell Mol Physiol 2002, 282:L968-975.

26. Beck-Speier I, Dayal N, Karg E, Maier KL, Schumann G, Schulz H, Semmler M, Takenaka S, Stettmaier K, Bors W, et al: Oxidative stress and lipid mediators induced in alveolar macrophages by ultrafine particles. Free Radic Biol Med 2005, 38:1080-1092.

27. Brown DM, Wilson MR, MacNee W, Stone V, Donaldson K: Size-dependent proinflammatory effects of ultrafine polystyrene particles: a role for surface area and oxidative stress in the enhanced activity of ultrafines. Toxicol Appl Pharmacol 2001, 175:191-199.

28. Mossman BT, Shukla A, Fukagawa NK: Highlight Commentary on "Oxidative stress and lipid mediators induced in alveolar macrophages by ultrafine particles". Free Radic Biol Med 2007, 43:504-505.

29. Guthrie GD Jr, Heaney PJ: Mineralogical characteristics of silica polymorphs in relation to their biological activities. Scand J Work Environ Health 1995, 21(Suppl 2):5-8.

30. Hillegass JM, Shukla A, MacPherson MB, Bond JP, Steele C, Mossman BT: Utilization of gene profiling and proteomics to determine mineral pathogenicity in a human mesothelial cell line (LP9/TERT-1). J Toxicol Environ Health A 2010, 73:423-436.

31. Hillegass JM, Shukla A, MacPherson MB, Lathrop SA, Alexeeva V, Perkins TN, van der Vliet A, Vacek PM, Gunter ME, Mossman BT: Mechanisms of oxidative stress and alterations in gene expression by Libby six-mix in human mesothelial cells. Part Fibre Toxicol 2010, 7:26.

32. Shukla A, MacPherson MB, Hillegass J, Ramos-Nino ME, Alexeeva V, Vacek PM, Bond JP, Pass HI, Steele C, Mossman BT: Alterations in gene expression in human mesothelial cells correlate with mineral pathogenicity. Am J Respir Cell Mol Biol 2009, 41:114-123.

33. Fubini $B$, Giamello E, Volante $M$, Bolis V: Chemical functionalities at the silica surface determining its reactivity when inhaled. Formation and reactivity of surface radicals. Toxicol Ind Health 1990, 6:571-598.

34. Fubini B, Zanetti G, Altilia S, Tiozzo R, Lison D, Saffiotti U: Relationship between surface properties and cellular responses to crystalline silica: studies with heat-treated cristobalite. Chem Res Toxicol 1999, 12:737-745.

35. Ghio AJ, Kennedy TP, Whorton AR, Crumbliss AL, Hatch GE, Hoidal JR: Role of surface complexed iron in oxidant generation and lung inflammation induced by silicates. Am J Physiol 1992, 263:L511-518.

36. Vallyathan V, Shi XL, Dalal NS, Irr W, Castranova V: Generation of free radicals from freshly fractured silica dust. Potential role in acute silicainduced lung injury. Am Rev Respir Dis 1988, 138:1213-1219.

37. Fubini B, Hubbard A: Reactive oxygen species (ROS) and reactive nitrogen species (RNS) generation by silica in inflammation and fibrosis. Free Radic Biol Med 2003, 34:1507-1516.

38. Fubini B, Fenoglio I, Elias Z, Poirot O: Variability of biological responses to silicas: effect of origin, crystallinity, and state of surface on generation of reactive oxygen species and morphological transformation of mammalian cells. J Environ Pathol Toxicol Oncol 2001, 20(Suppl 1):95-108.

39. Johnston CJ, Driscoll KE, Finkelstein JN, Baggs R, O'Reilly MA, Carter J, Gelein R, Oberdorster G: Pulmonary chemokine and mutagenic responses in rats after subchronic inhalation of amorphous and crystalline silica. Toxicol Sci 2000, 56:405-413.

40. Warheit DB: Inhaled amorphous silica particulates: what do we know about their toxicological profiles? J Environ Pathol Toxicol Oncol 2001, 20(Suppl 1):133-141.

41. Huang YC, Karoly ED, Dailey LA, Schmitt MT, Silbajoris R, Graff DW, Devlin RB: Comparison of gene expression profiles induced by coarse, fine, and ultrafine particulate matter. J Toxicol Environ Health A 2011, 74:296-312.

42. Belitskaya-Levy I, Hajjou M, Su WC, Yie TA, Tchou-Wong KM, Tang MS, Goldberg JD, Rom WN: Gene profiling of normal human bronchial epithelial cells in response to asbestos and benzo(a)pyrene diol epoxide (BPDE). J Environ Pathol Toxicol Oncol 2007, 26:281-294.

43. McDermott JE, Archuleta M, Thrall BD, Adkins JN, Waters KM: Controlling the response: predictive modeling of a highly central, pathogentargeted core response module in macrophage activation. PLoS One 2011, 6:e14673.

44. Heintz NH, Janssen YM, Mossman BT: Persistent induction of c-fos and cjun expression by asbestos. Proc Natl Acad Sci USA 1993, 90:3299-3303.

45. Barrett EG, Johnston C, Oberdorster G, Finkelstein JN: Silica-induced chemokine expression in alveolar type II cells is mediated by TNF-alpha. Am J Physiol 1998, 275:L1110-1119.

46. Hetland RB, Schwarze PE, Johansen BV, Myran T, Uthus N, Refsnes M: Silicainduced cytokine release from A549 cells: importance of surface area versus size. Hum Exp Toxicol 2001, 20:46-55.

47. Ovrevik J, Lag M, Holme JA, Schwarze PE, Refsnes M: Cytokine and chemokine expression patterns in lung epithelial cells exposed to components characteristic of particulate air pollution. Toxicology 2009, 259:46-53.

48. Ovrevik J, Refsnes M, Namork E, Becher R, Sandnes D, Schwarze PE, Lag M: Mechanisms of silica-induced IL-8 release from A549 cells: initial kinaseactivation does not require EGFR activation or particle uptake. Toxicology 2006, 227:105-116.

49. Ovrevik J, Myran T, Refsnes M, Lag M, Becher R, Hetland RB, Schwarze PE: Mineral particles of varying composition induce differential chemokine release from epithelial lung cells: importance of physico-chemical characteristics. Ann Occup Hyg 2005, 49:219-231.

50. Shukla A, Timblin CR, Hubbard AK, Bravman J, Mossman BT: Silica-induced activation of c-Jun- $\mathrm{NH} 2$-terminal amino kinases, protracted expression of the activator protein-1 proto-oncogene, fra-1, and S-phase alterations are mediated via oxidative stress. Cancer Res 2001, 61:1791-1795.

51. Nymark P, Lindholm PM, Korpela MV, Lahti L, Ruosaari S, Kaski S, Hollmen J, Anttila S, Kinnula VL, Knuutila S: Gene expression profiles in asbestosexposed epithelial and mesothelial lung cell lines. BMC Genomics 2007, 8:62.

52. Hengstermann A, Muller T: Endoplasmic reticulum stress induced by aqueous extracts of cigarette smoke in 3T3 cells activates the unfoldedprotein-response-dependent PERK pathway of cell survival. Free Radic Biol Med 2008, 44:1097-1107.

53. Davis GS, Pfeiffer LM, Hemenway DR, Rincon M: Interleukin-12 is not essential for silicosis in mice. Part Fibre Toxicol 2006, 3:2.

54. Beamer CA, Migliaccio CT, Jessop F, Trapkus M, Yuan D, Holian A: Innate immune processes are sufficient for driving silicosis in mice. J Leukoc Biol 2010, 88:547-557.

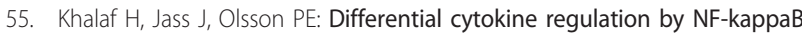
and AP-1 in Jurkat T-cells. BMC Immunol 2010, 11:26.

56. Kube D, Sontich U, Fletcher D, Davis PB: Proinflammatory cytokine responses to $P$. aeruginosa infection in human airway epithelial cell lines. Am J Physiol Lung Cell Mol Physiol 2001, 280:L493-502.

57. Wedzicha JA, Seemungal TA, MacCallum PK, Paul EA, Donaldson GC, Bhowmik A, Jeffries DJ, Meade TW: Acute exacerbations of chronic obstructive pulmonary disease are accompanied by elevations of plasma fibrinogen and serum IL-6 levels. Thromb Haemost 2000, 84:210-215.

58. Stecenko AA, King G, Torii K, Breyer RM, Dworski R, Blackwell TS, Christman JW, Brigham KL: Dysregulated cytokine production in human cystic fibrosis bronchial epithelial cells. Inflammation 2001, 25:145-155.

59. Zhai R, Ge X, Li H, Tang Z, Liao R, Kleinjans J: Differences in cellular and inflammatory cytokine profiles in the bronchoalveolar lavage fluid in bagassosis and silicosis. Am J Ind Med 2004, 46:338-344.

60. Miller MD, Krangel MS: Biology and biochemistry of the chemokines: a family of chemotactic and inflammatory cytokines. Crit Rev Immunol 1992, 12:17-46. 
61. Hamilton JA: Colony-stimulating factors in inflammation and autoimmunity. Nat Rev Immunol 2008, 8:533-544.

62. Yao W, Feng FF, Jiao J, Wang N: [Expression level and significance of TGFbeta1, PDGF, CTGF in serum of patients with pneumoconiosis]. Sichuan Da Xue Xue Bao Yi Xue Ban 2006, 37:754-756, 793.

63. Brandt-Rauf PW, Smith S, Hemminki K, Koskinen H, Vainio H, Niman $H$, Ford J: Serum oncoproteins and growth factors in asbestosis and silicosis patients. Int J Cancer 1992, 50:881-885.

64. Ando M, Miyazaki E, Ito T, Hiroshige S, Nureki SI, Ueno T, Takenaka R, Fukami T, Kumamoto T: Significance of serum vascular endothelial growth factor level in patients with idiopathic pulmonary fibrosis. Lung 2010, 188:247-252

65. Stockmann C, Kerdiles Y, Nomaksteinsky M, Weidemann A, Takeda N, Doedens A, Torres-Collado AX, Iruela-Arispe L, Nizet V, Johnson RS: Loss of myeloid cell-derived vascular endothelial growth factor accelerates fibrosis. Proc Natl Acad Sci USA 2010, 107:4329-4334.

66. Bodo M, Baroni T, Bellocchio S, Calvitti M, Lilli C, D'Alessandro A, Muzi G, Lumare A, Abbritti G: Bronchial epithelial cell matrix production in response to silica and basic fibroblast growth factor. Mol Med 2001, 7:83-92.

67. Herseth JI, Volden V, Schwarze PE, Lag M, Refsnes M: IL-1 beta differently involved in IL-8 and FGF-2 release in crystalline silica-treated lung cell co-cultures. Part Fibre Toxicol 2008, 5:16.

68. Selige J, Tenor H, Hatzelmann A, Dunkern T: Cytokine-dependent balance of mitogenic effects in primary human lung fibroblasts related to cyclic AMP signaling and phosphodiesterase 4 inhibition. J Cell Physiol 2010, 223:317-326.

69. Shirakihara T, Horiguchi K, Miyazawa K, Ehata S, Shibata T, Morita I, Miyazono K, Saitoh M: TGF-beta regulates isoform switching of FGF receptors and epithelial-mesenchymal transition. EMBO J 2011, 30:783-795.

70. Khalil N, Xu YD, O'Connor R, Duronio V: Proliferation of pulmonary interstitial fibroblasts is mediated by transforming growth factor-beta1induced release of extracellular fibroblast growth factor- 2 and phosphorylation of p38 MAPK and JNK. J Biol Chem 2005, 280:43000-43009.

71. Hamada H, Vallyathan V, Cool CD, Barker E, Inoue Y, Newman LS: Mast cell basic fibroblast growth factor in silicosis. Am J Respir Crit Care Med 2000, 161:2026-2034

72. Zhou R, Tardivel A, Thorens B, Choi I, Tschopp J: Thioredoxin-interacting protein links oxidative stress to inflammasome activation. Nat Immunol 2010, 11:136-140.

73. Dostert C, Petrilli V, Van Bruggen R, Steele C, Mossman BT, Tschopp J: Innate immune activation through Nalp3 inflammasome sensing of asbestos and silica. Science 2008, 320:674-677.

74. Timblin CR, Shukla A, Berlanger I, BeruBe KA, Churg A, Mossman BT: Ultrafine airborne particles cause increases in protooncogene expression and proliferation in alveolar epithelial cells. Toxicol Appl Pharmacol 2002, 179:98-104.

75. De G, Karmakar B, Ganguli D: Hydrolysis-condensation reactions of TEOS in the presence of acetic acid leading to the generation of glass-like silica microspheres in solution at room temperature. J Mater Chem 2000, 10:2289-2293.

76. Kruk M, Antochshuk V, Jaroniec M, Sayari A: New approach to evaluate pore size distributions and surface areas for hydrophobic mesoporous solids. J Phys Chem B 1999, 103:10670-10678.

77. Kruk M, Jaroniec M, Sakamoto Y, Terasaki O, Ryoo R, Ko CH: Determination of pore size and pore wall structure of MCM- 41 by using nitrogen adsorption, transmission electron microscopy, and X-ray diffraction. J Phys Chem B 2000, 104:292-301.

78. Kruk M, Jaroniec M, Sayari A: Application of large pore MCM-41 molecular sieves to improve pore size analysis using nitrogen adsorption measurements. Langmuir 1997, 13:6267-6273.

79. Hillegass JM, Shukla A, Lathrop SA, MacPherson MB, Fukagawa NK, Mossman BT: Assessing nanotoxicity in cells in vitro. Wiley Interdiscip Rev Nanomed Nanobiotechnol 2010, 2:219-231.

80. Shukla A, Lounsbury KM, Barrett TF, Gell J, Rincon M, Butnor K, Taatjes DJ, Davis GS, Vacek P, Nakayama Kl, et al: Asbestos-induced peribronchiolar cell proliferation and cytokine production are attenuated in lungs of protein kinase C-delta knockout mice. Am J Pathol 2007, 170:140-151.
81. Sabo-Attwood T, Ramos-Nino M, Bond J, Butnor K, Heintz N, Gruber AD, Steele C, Taatjes DJ, Vacek P, Mossman BT: Gene expression profiles reveal increased mClca3 (Gob5) expression and mucin production in a murine model of asbestos-induced fibrogenesis. Am J Pathol 2005, 167:1243-1256.

doi:10.1186/1743-8977-9-6

Cite this article as: Perkins et al:: Differences in gene expression and cytokine production by crystalline vs. amorphous silica in human lung epithelial cells. Particle and Fibre Toxicology 2012 9:6.

\section{Submit your next manuscript to BioMed Central and take full advantage of:}

- Convenient online submission

- Thorough peer review

- No space constraints or color figure charges

- Immediate publication on acceptance

- Inclusion in PubMed, CAS, Scopus and Google Scholar

- Research which is freely available for redistribution

Submit your manuscript at www.biomedcentral.com/submit
Biomed Central 